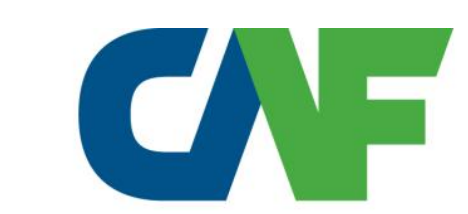

FINANCIANDO EL DESARROLLO • AMÉRICA LATINA

CAF

DOCUMENTOS DE TRABAJO

CAF

WORKING PAPERS

\title{
CONTRACTING THE ROAD TO DEVELOPMENT: EARLY IMPACTS OF A RURAL ROADS PROGRAM
}

$N^{\circ} 2009 / 10$

September, 2009

Valdivia, Martín

CAF - Ave. Luis Roche, Torre CAF, Altamira. Caracas, Venezuela 01060

(C) CAF, 2009 por Valdivia, Martín. Todos los derechos reservados. Pequeñas secciones del texto, menores a dos párrafos, pueden ser citadas sin autorización explícita siempre que se cite el presente documento.

Los resultados, interpretaciones y conclusiones expresados en esta publicación son de exclusiva responsabilidad de su(s) autor(es), y de ninguna manera pueden ser atribuidos a CAF, a los miembros de su Directorio Ejecutivo o a los países que ellos representan.

CAF no garantiza la exactitud de los datos incluidos en esta publicación y no se hace responsable en ningún aspecto de las consecuencias que resulten de su utilización. 
CONTRATANDO EL CAMINO AL DESARROLLO: IMPACTOS TEMPRANOS DE UN PROGRAMA DE CARRETERAS RURALES

Valdivia, Martín

CAF Documento de trabajo № 2009/10

Septiembre 2009

\section{RESUMEN}

En el presente trabajo se estudian los impactos iniciales del Programa de Caminos Rurales (PCR) peruano que está caracterizado por la contratación de empresas locales privadas para la rehabilitación y mantenimiento de los caminos rurales bajo supervisión local por parte de los líderes comunitarios, estableciendo incentivos en favor de actividades preventivas y de mantenimiento continuo y oportuno de los caminos rurales. Se encontró que esta innovación institucional mejora el tránsito de las vías, lo que genera un incremento del ingreso, un cambio en los patrones de empleo y mayores inversiones en educación y salud, diferenciándose enormemente según las características del individuo, los hogares, los pueblos y las vías tratadas. En particular, es interesante encontrar que el efecto ingreso inicial detentado en los hogares se asocia a las vías sin tráfico automotor y que el cambio en los patrones de empleo se corresponde más con el género femenino. Por otra parte, la exclusión de las hijas mayores de los efectos positivos asociados a la asistencia escolar, requiere de un entendimiento más profundo de los factores que se encuentran detrás de esta desigualdad de géneros. Así que, los resultados de esta temprana evaluación de los impactos del PCR peruano son bastante positivos, a pesar que dicho programa no incluya la construcción de nuevas vías o su cambio de categoría, como es el caso de otros países para los que los resultados de programas similares han venido evaluándose recientemente. La contratación de empresas privadas locales para la rehabilitación y mantenimiento de los caminos rurales en los países en desarrollo podría tener impactos sociales y económicos significativos en pro de la pobreza, especialmente si los programas incluyen trayectos no motorizados, ya que ellos prestan un mayor servicio a las actividades de las mujeres en hogares más pobres.

Palabras clave: Perú, programa de carreteras rurales 
CONTRACTING THE ROAD TO DEVELOPMENT: EARLY IMPACTS OF A RURAL ROADS PROGRAM

Valdivia, Martín

CAF Working paper $\mathrm{N}^{\circ} 2009 / 10$

September, 2009

\begin{abstract}
We studied here the early impacts of the Peruvian rural roads program (RRP) that is characterized by the contracting of private local firms for the rehabilitation and maintenance of rural roads with local supervision by community leaders setting incentives that favour prevention activities and a sustainable and timely maintenance of rural roads. We find that this institutional innovation improved road transitability which in turn led to increased income, change in employment patterns and increased investments in education and health, although they differ greatly by the characteristics of the individual, household, villages and treated road. In particular, it is interesting to find that early income effects accrue in households associated to non-motorized tracks and that the change in employment patterns focus on women. On the other side, the exclusion of older girls from the positive effects on school attendance urges for a deeper understanding of the factors behind this source of gender inequities. Thus, the results of this early evaluation are very positive about the impacts of the Peruvian RRP, even though it does not include construction of new roads or their upgrading as it is the case in programs recently evaluated. The contracting of local private firms for the rehabilitation and maintenance of rural roads in developing countries may have meaningful pro-poor social and economic impacts, especially if programs include non-motorized tracks as they best serve the activities of women in poorer households
\end{abstract}

Keywords: Peru, rural roads program

Martín Valdivia

Grupo de Análisis para el Desarrollo (GRADE)

jvaldivi@grade.org.pe 


\title{
CONTRACTING THE ROAD TO DEVELOPMENT: EARLY IMPACTS OF A RURAL ROADS PROGRAM ${ }^{1}$
}

\author{
Martín Valdivia \\ Grupo de Análisis para el Desarrollo (GRADE)
}

\begin{abstract}
We study here the early impacts of the Peruvian rural roads program (RRP), characterized by a decentralized mechanism that contracts private local firms for the rehabilitation and maintenance of rural roads with local supervision by community leaders setting incentives that favour prevention activities and a sustainable and timely maintenance of rural roads. The analysis is based on a quasiexperimental approach through which control roads are defined prior to the intervention based on key observable characteristics of the road and the villages they connect. Diff-in-Diff estimates are reported to control for biases associated to time-invariant unobservables. We find that this institutional innovation improved road transitability which in turn led to significant changes in employment patterns, increased investments in education and health. Income effects are not significant on average, but they appear strong in villages with pre-existent endowments of key productive infrastructure, favouring the notion that road improvements need to be complemented with additional investments to effectively contribute to the reduction of rural poverty. Most of these results, though, are concentrated on interventions in motorized roads, although the inclusion of nonmotorized tracks is supported by the empowering of women's participation in farm activities. Thus, the results of this early evaluation are encouraging about the impacts of the Peruvian RRP, as they indicate that the intervention has been able to control local capture and corruption threats.
\end{abstract}

JEL codes: H54, H70, L33, O12

September, 2009

${ }^{1}$ Author's e-mail: jvaldivi@grade.org.pe. The author wishes to thank officials from PROVIAS DESCENTRALIZADO for the permission to use the data for this study and to the PEP Research Network, CIES and CAF for financial support. This version has benefited from insightful and helpful comments by Sonia Laszlo, Sam Morley and participants of seminars at CAF, NEUDC, PEP, GRADE, CEA and LACEA. The author also acknowledges the valuable support of Vanessa Cheng, Valerie Koechlin, Paola Vargas and Rosa Vidarte at different stages of the project, in the supervision of the data collection of the 2006 round and with the data analysis. Usual disclaimer applies. 


\section{Introduction}

The economic literature has been increasingly reporting mechanisms through which improved roads can create opportunities for economic growth and poverty reduction in rural economies (Binswanger, Khandker and Rosenzweig, 1993; among others). Through the reduction of transportation costs, improved roads can increase productivity and demand for labor in farm and non-farm activities thus leading to increased income and consumption. Although often ignored until recently, improved roads can also have meaningful social impacts, in particular those associated to household investments in health and education (van de Walle, 2002).

Nevertheless, macroeconomic adjustments and local governance issues have led to underinvestment in this kind of infrastructure (World Bank, 2005). Moreover, rural transport projects have focused on building new roads or upgrading their condition, while disregarding the need to establish an institutional arrangement to guarantee timely rehabilitation and maintenance of roads (Malmberg Calvo, 1998). In that sense, the focus of the Peruvian Rural Roads Project (RRP) on an institutional innovation that focuses on the rehabilitation and permanent maintenance of already existent rural roads, for which local private firms are promoted and contracted, makes it particularly important to be analyzed. That is, public funds are provided not only for a one-time rehabilitation but also for

permanent maintenance of treated roads, and payments to contracted local firms require a satisfactory report from PROVIAS and community supervisors. To my knowledge, there does not exist a study with a careful evaluation of the impacts of a road program that focus on a similar institutional innovation. 
The analysis of this kind of interventions is particularly relevant in the current wave of decentralization in the provision of infrastructure in the developing world. Decentralization to local governments combined with community participation can increase accountability of providers leading towards a quality increase in service provision (World Bank, 2004). However, more recent studies have been more cautious about the ultimate effects of decentralization and community participation on the quality in the provision of infrastructure. Local capture and corruption can make provision of infrastructure worse under decentralized mechanisms (Bardhan and Mookherjee, 2006; Olken, 2007). More empirical evidence is needed to see which of the trends end up dominating under different contexts.

Focusing on the Peruvian RRP, this paper attempts to contribute to the literature by evaluating the impacts of a unique program that focuses on an institutional innovation to improve road rehabilitation and permanent maintenance. The research questions are whether we can define a decentralized mechanism or contract that can improve the quality of rural roads in developing countries, and whether that would lead to increased income and human capital investments. With respect to the mechanism question, one point is whether including permanent road maintenance alters the nature of the contract enough, making local capture and corruption more complicated, and increasing the likelihood of improved quality of rural roads. With respect to the welfare effects of improved roads, a key issue is to analyze whether time has been enough for effects to materialize, or whether 
complementary investments are required ${ }^{2}$. In addition, it is relevant to see whether a program that focus exclusively in rehabilitation and maintenance of rural roads, excluding any new roads or road upgrading, can generate sizable welfare effects. Most of the interventions reported in the literature, especially in Africa and Asia, include building new roads or upgrading them, for instance, by paving them, while disregarding regular maintenance. Indeed, the Peruvian RRP does not include pavement upgrades as in the Blangladesh case analyzed by Khandker et. al. (2006) nor includes building new roads as in the Vietnamese case studied by Mu and van de Walle (2007).

Methodologically, we use a quasi-experimental approach that allows controlling for time-invariant unobserved characteristics of villages and households. Although, we define a control group based on a rich set of observables, road rehabilitation and maintenance activities by other agencies are not banned in control roads, so that the impacts we report here are associated to an improved efficiency in road rehabilitation and maintenance with the program rather than to the absolute lack of these efforts on the part of other public agencies such as local governments, or others. To my knowledge, there is no published study that focuses on such institutional innovation. We use a longitudinal dataset that enables us to measure impacts on a wide variety of socio-economic, institutional and environmental characteristics. Furthermore, we also explore the heterogeneity in the impacts by individual, household and village characteristics, as well as conditioning

\footnotetext{
${ }^{2}$ Although the Peruvian RRP has been operating since 1998, this study focuses on the impact of the cohort of interventions that started in 2004, and evaluates its impacts after only two years. That is, the estimated impacts we are presenting here need to be interpreted as the very early impacts of the improvement in rural roads generated by the institutional innovation.
} 
community factors for the realization of benefits. In particular, we analyze the extent to which poorer households, smaller communities, rural women, and other especially marginalized groups, benefit from the enhanced economic environment resulting from the Peruvian RRP. Policy makers would greatly benefit from identifying a conditional factor, either at the level of the community or the household, that spurs the impact of improved rural roads. However, if the key conditional factor varies too much by outcome so that no general pattern can be identified, targeting policy implications would be less clear.

This paper is organized in five sections including this introduction. The second section presents the key features of the intervention and discusses the expected effects. Section 3 describes the characteristics of the data and the methodology used for estimating the impact of the Peruvian RRP. Section 4 presents the estimated impacts on the quality of the roads, and its effects on household income and expenditures, employment, as well as investments in education and health. Section 5 summarizes the results and discusses its limitations as well as some of its potential policy implications.

\section{The program and its expected effects}

The Peruvian RRP is a large program run by the PROVIAS RURAL, a unit of the Viceminister of Transport that has been operating since 1995 with the objective to improve transport conditions in rural villages by contracting private local firms to manage and carry 
out, on a sustainable basis, the maintenance of rural roads in the poorest areas of Peru ${ }^{3}$. The first phase of the RRP was carried out during 1995-2000 in 12 departments that ranked highest in rural poverty within the country. During that first phase, the project improved rural accessibility in 314 districts contracting with 495 local firms in charge of rehabilitating and maintaining about 12,000 kilometers of rural roads and key secondary roads and about 3,000 km of non-motorized tracks (Escobal, et. al., op. cit.) ${ }^{4}$.

\subsection{The intervention}

The RRP program is based on an institutional innovation that focuses on setting the right incentives and strengthening local governments and firms to improve rehabilitation and maintenance of already existent rural unpaved roads and non-motorized tracks. Rural roads in Peru are the responsibility of provincial and district governments since the Law of Municipalities of $2004^{5}$. However, ambiguities, overlaps in responsibilities of different levels of governments, and lack of financial and institutional resources al the local level have allowed for avoidance of accountability in the maintenance of rural roads (World Bank, 1995). When a road is blocked due to floods or other weather shocks, local governments start rehabilitation with technical and financial support from the regional or

${ }^{3}$ Currently, the unit running the program is called PERU DESCENTRALIZADO, an indication of the increased role of local governments in the planning and execution of the program, as part of the decentralization process being carried out within the Peruvian State.

${ }^{4}$ The system of district-level rural roads in Peru is estimated in 70,000 kilometers. In the 12 departments the system of rural roads is estimated in 28,000 kilometers.

${ }^{5}$ Traditionally, as a typical centralized government, all roads were the responsibility of the Ministry of Transport and Communications (MTC). The Regionalization law of 2004 transferred all roads to regional and local governments. The mandate was partially reversed in 1991, as MTC was 
central government, although the process tends to be slow. Responsibility is even less clear for regular maintenance as, for instance, it is not clear where the users can complain to for excessive bumpings and stones in the roads, which in turn increase travel time as well as maintaining costs for public and private vehicles.

The Peruvian RRP is clearly framed by the decentralization process that has been developing in Peru over the last two decades. It commits financing from the central government, works with local governments in the planning of activities, and assigns the responsibility of performing quality rehabilitation and permanent maintenance of selected rural roads to local private firms through contracts that connect regular payments to the quality of the road as periodically assessed by officials from both the program and local governments, as well as community organizations. This assessment is not limited to checking the materials the local firms use in the rehabilitation activities, as it can also use observable final outcomes such as travel time to go from startpoint to endpoint of the road segment, the number of months the road is blocked due to landslides during rainy season, or the bumpiness of the road as it increase maintenance costs for private and public motorized vehicles. Observability of these outcomes helps to make local authorities and contracted firms accountable for the quality of maintenance. Thus, in principle, incentives are set for local contractors to implement a more regular maintenance, including maintenance of road drainage systems as they that could prevent blockages, or other

reassigned to the national road network, although departmental and rural roads remained at the level of the regional and local governments, respectively. 
activities that reduce costs of rehabilitation when weather shocks hit transitability of the road.

Nevertheless, the incentive structure can be damaged if the program is captured by local elites as the supervision by local authorities can become a formality. Olken (2007) reports the case of the Indonesian rural road program affected by corruption, as measured by the discrepancies between reported budgets and the budgets estimated by special supervisors based on an analysis of materials and labor used. However, it is important to notice that the Indonesian RRP, as opposed to the Peruvian RRP, does not include regular maintenance so that incentives cannot be set based on observable qualities of the road, and only by costly monitoring of the actual materials used during the construction, upgrading or rehabilitation. This evaluation would allow us to see whether the program's incentive structure have so far been able to control local capture and corruption threats, after a decade at work.

The institutional innovation in the Peruvian RRP depends critically on the quality of local institutions, including local authorities and firms (Malmberg, 1998). Thus, the RRP promotes local institutional development by providing technical assistance to local governments and small and medium local enterprises for improved planning and management of rural roads and for the development of micro-enterprises formed by groups of beneficiaries for road maintenance. The program has a local office in every department which starts by identifying the provinces in which they will operate in each stage. Once a province is identified, the program starts with the formation of a Provincial Road Institute (PRI) with increasing participation of the provincial municipality and other local 
authorities. The program's departmental office coordinates with the PRI to select the specific road segments to be rehabilitated and maintained at each stage, with participation of other local institutions through open consultations in different districts.

Once a road has been selected for intervention, local officials from the program and local authorities coordinate to initiate the intervention with an open call for individuals interested in becoming members of the local microenterprise of road maintenance (MEMV, for its name in spanish) that is going to be in charge of the periodic rehabilitation and maintenance of the selected road (Escobal, et. al., 2005). They are then selected based on their previous experience in road maintenance, time of residence in the locality, as well as characteristics such as education, age, etc. The selected individuals are then trained in the management of the microenterprise and maintenance of the road and the MEMV is legally formed. Next, the program's local officers elaborate the annual plan of activities using a program that allows the calculation of the number of individuals and time required to rehabilitate and maintain the selected road as well as the cost per kilometer ${ }^{6}$. These estimates are based on the characteristics of the selected road such as its location, length, width, traffic and weather conditions. MEMVs then sign a contract with PROVIAS RURAL through which they receive monthly payments, based on the estimated costs and a quality certification issued monthly by the PROVIAS and community supervisors ${ }^{7}$. As mentioned above, these output-based contracts set clear incentives for the local MEMV to

\footnotetext{
${ }^{6}$ Escobal et. al., op. cit., reports that average costs are US \$ 17,000 per kilometer rehabilitated and US \$2,800 per kilometer maintained.
} 
invest in prevention activities and provide a sustained and timely maintenance of the contracted rural road (Benavides, 2003).

In terms of the kind of rural roads targeted by the program, it is important to point out that, unlike previous cases recently analyzed in the literature, the Peruvian RRP does not include road paving or the building of new roads. Second, the program not only considers unpaved motorized roads but also non-motorized tracks. The gradual inclusion of nonmotorized tracks aims at promoting gender equity in the distribution of the intervention's impacts as these tracks were identified as the ones women use most ${ }^{8}$.

\subsection{Expected effects}

Setting the right incentives for contracted local firms should improve quality rehabilitation and maintenance of rural roads treated by the program, reducing the time they remain blocked when large weather shocks hit, and also reducing the time required to travel across the different points connected by the selected roads. Thus, we can expect the program to better integrate poorly accessible zones to regional economic centers, reducing transport costs and raising the reliability of vehicular access to expand markets for agricultural and non-farm products and enhancing a more diversified set of employment opportunities for

${ }^{7}$ In case of an unsatisfactory maintenance, supervisors give time to the MEMV to repair the deficiencies. If the situation is not solved, the local office applies discounts to the monthly payments, and the contract is dissolved if the deficiencies occur over three consecutive months.

${ }^{8}$ The program identified this fact when collected the opinions of potential beneficiaries through gender-based focus groups organized in several rural communities (see Fort and Menendez, 2005). Additional focus groups after the intervention have confirmed that a large proportion of women see the program's road intervention enabling them to travel farther and more safely, and has also led to increased income. 
rural households. Improved transportation will also reduce time to reach basic social services such as health, education and justice.

However, it is important to clarify here that our counterfactual is not complete inaction with respect to the rehabilitation of maintenance of control rural roads. Control roads may not have guaranteed financing for rehabilitation and maintenance, nor a specific agent with the clear responsibility and incentives to perform the actual physical works. Thus, control roads may take longer to be rehabilitated after a flood, or have bumps and stones that increase travel time and maintenance costs for vehicles. Still, local governments and other offices of the Ministry of Transport and Communications (MTC) and public agencies such as FONCODES may have performed related activities in control roads, especially when weather shocks blocked them. Thus, rather than the impacts of rehabilitating and maintaining a rural road, this study evaluates the effects associated to the improved efficiency in these rehabilitation and maintenance activities as a result of the reallocation of incentives due to output-based contracts that favor prevention and sustained and timely maintenance by local contractors ${ }^{9}$.

Many papers have shown the different mechanisms through which improved rural roads benefit the welfare of households and individuals associated to beneficiary roads $(\mathrm{Mu}$ and van de Walle, 2007; Khandker, et. al., 2006; Levy, 2004; Escobal y Ponce, 2002; Jacoby, 2000; among others). We briefly summarize the most important findings of that

\footnotetext{
${ }^{9}$ This issue is particularly important in the case of the Peruvian RRP, as local governments have seen a substantial increase in their budgets as a result of the decentralization process, and the RRP intervention does not include road upgrading as in the Blangladesh case analyzed by Khandker et.
} 
literature, with some extra comments regarding the sequence of effects as they may affect the time needed for some of these effects to materialize. The most direct effects of the RRP are associated to the transitability of the rural roads, which are often estimated through the travel time needed to go from the initial to end points of the segment of the reference and the time (weeks or months in a year) a road stays blocked due to a climatic shock or alike. Levy (2004), for instance, report such effects in Morocco, emphasizing on the importance of the number of months the road remained blocked in the context of rural roads. Other subsequent effects are reduced time that individuals residing in the connected villages take on average to go to key markets, schools, health facilities, depending on the nature of the role of the segment on the local road network. At the same time, the improved transitability may eventually lead to an improved public transportation service that can be measured in terms of an increased frequency of buses or reduced prices for the transportation of individuals and cargo. The latter effects are clearly conditioned on the improved transitability of treated roads, and thus they are likely to take longer to materialize.

The improved rural roads activate a series of mechanisms that transform traditional productive patterns, agricultural and non-agricultural, in the villages associated to the rehabilitated segments. First, reduced travel times help individuals access to extra off-farm employment opportunities both, agricultural and non-agricultural, within and outside the village. Escobal and Ponce (2002) find such result for the first round of interventions by the Peruvian RPP, especially non-agricultural wage employment for more educated

al. (2006) nor building new roads as in the Vietnamese case studied by $\mathrm{Mu}$ and van de Walle (2007). 
individuals. Jacoby (2000) also argues for such effects as he finds a negative correlation between agricultural and non-agricultural wages and the distance from the village to the key markets in Nepal.

Farm productivity and income can also receive a boost as a result of reduced postharvest crop losses, lower input prices, higher output prices or improved access to financial and non-financial agricultural services, (Biswanger, Khandker and Rosenzweig, 1993). Improved accessibility to markets increases small farmer's bargaining power with local traders. Access to credit and agricultural extension services may take longer and come first for less poor farmers or in villages closer to larger markets, as they tend to require extra conditions such as mechanisms for agricultural risk management and organization of small local farmers. Access to these services is seen as crucial for small farmers to switch towards high-value crops.

However, these effects have not been found in all cases and often concentrated on less poor farmers, consistent with the fact that complementary investments are required for them to materialize. Moreover, income effects may at least initially be perceived as temporary and consequently households decide to increase savings through increments in livestock rather than increased consumption (Escobal and Ponce, 2002). More important for this study is the fact that many of these effects are conditioned on adjustments in the supply of key agricultural services such as agricultural extension, credit, which may take longer to materialize. Thus, it would not be that surprising if we do not find income effects in this study, especially if we consider that the follow up in which this study is based comes only two years since treated roads started being served by the program. 
Improved rural roads cannot only spur productivity and income but also household investments in the human capital of their children. As travel times are reduced, it is less costly for parents to send their younger children to school as they would need to devote less time traveling with them to the school location. Older children would in turn be able to attend school while at the same time being able to help with housework or at the family farm. Levy (2004), for instance, finds increased school attendance, especially among girls, which may imply that improved travel security may also be an important factor for rural girls. These demand-side effects are likely to show up early. But supply-side effects may also increase household investments in schooling as quality can improve as a result of more effective attendance by teachers or even improved recruiting as a result of reduced travel times to larger villages or the capital of the district. However, the teacher's recruiting effect may be expected to take longer to show up.

Similar mechanisms can be stated to explain improved access to health services. With improved roads, visits to health facilities may take less time for the ill individual or the family member in charge of their care. The attendance and recruiting effects can be raised for doctors and other health professionals, in the same way they were mentioned for school teachers. In addition, improved roads can also help bring social programs based on health facilities closer to the associated villages, increasing access to preventive health programs that could reduce sickness events among children and adults. Qualitative studies in SubSaharan Africa and Asia have reported that individuals identify improved access to health services as the key benefit obtained from improved roads (see, for instance, Porter, 2002 and Hettige, 2006). 
All these positive effects may significantly alter the socio-economic context in the villages associated to the improved roads so that migration incentives in search of better employment and education opportunities may be reduced. However, at the same time, permanent and temporary migration costs are reduced. Thus, the net effect of improved roads on permanent and temporary migration may go either way.

In sum, we have seen a wide variety of potential impacts of the Peruvian RRPs. However, not all of them are likely to show up in this early evaluation after just two years. It is also likely that the size and time lags of these effects may vary across households and villages depending on the initial endowments of private and public assets. Poverty in developing countries is strongly concentrated in rural areas, but still there is significant heterogeneity that can lead to differentiated impacts and have important implications for project design. If higher or faster impacts are found in households and villages initially less endowed, policy makers will face a much desired win-win situation. However, if higher impacts concentrate among the initially better endowed, targeting for higher impacts may lead to increased inequalities within rural economies. Khandker et. al. (2006) and Mu and van de Walle (2007) explore the nature of these heterogeneities finding that road improvements tend to be pro-poor in rural Bangladesh and Vietnam, respectively, a very encouraging result. However, peculiarities of the Peruvian RRP demands for us to analyze whether such trend is sustained when the intervention does not include road upgrades, but instead a permanent maintenance component for both unpaved motorized roads and nonmotorized tracks. 


\section{Design, data and methodology}

\subsection{Quasi-experimental design}

For this intervention, treatment and control roads are not chosen randomly from a set of eligible roads. Instead, treatment roads are first selected by a departmental committee (program officials and local authorities) that chooses the provinces to be intervened. Then, the PRI and the local program officials picked the specific road to be intervened at a particular round. For this treatment group, a control group was selected prior to any intervention based on similarities in key observable variables such as the longitude and type of road (rural road or non-motorized track), characteristics of the villages involved such as population size, access to basic public services and infrastructure, altitude ${ }^{10}$.

Another important matched variable is the hierarchy of the villages involved, so that if a district capital was involved in the treated road, the control road also connected a district capital. In addition, control roads are also required to have no intersection with a treated road or track to minimize the probability that benefits on treated villages spill over the control villages. Actually, control roads were selected within the same province but from different districts to minimize the possibility they belonged to the same road network as the treated ones but at different stages. This effort was based on information provided by three key databases: the 1999 Pre-census database (INEI), the Population Census of 2005 (INEI) and the Geo-referenced Road Map (MINTRA-MINEDU), which is rarely available in a digital format for use in economics research. Table 3 shows the pre-treatment means 
for treatment and control groups for many observable variables, showing there are almost not statistically significant differences between these two groups ${ }^{11}$.

The selection process described for this intervention has important implications for the interpretation of the impact estimates we present here. First, it implies that our indicator would estimate a treatment on the treated effect. The relationship between our estimates and the average treatment effects would depend on the nature of the prioritization. If the PRI selected roads associated to poorest and most remote villages, and those would be the ones for which the RRP impacts are smallest, then our estimates would be underestimating the average effects. On the other hand, if roads where selected so that impacts would be largest, and these officials were right in their ex-ante assessments, then our estimates would be overestimating the average treatment effect.

Second, the selection may affect our ability to identify a proper control group. The selection may be so acute that the likelihood of identifying a road similar in all characteristics to the treated ones is rather low. We argue, though, that the size of the intervention in any province and department and the measures taken by our team helped contain such potential problem. A key issue is to avoid choosing as controls roads that are systematically located at different points of the road network. For that, besides similarities in access to key infrastructure, altitude, and population, we argue the hierarchy of the towns is crucial. That is, if a capital of a district is associated to the treated road, we look for another road that connects another capital of district to a similar ending town. In general,

\footnotetext{
${ }^{10}$ Treated and control roads are associated to villages by defining the origin and the end of the road.
} 
for each treated road, we restrict the search to different districts within the same province. However, when one of the towns was sensibly different from the rest available in the province, we looked in the adjacent provinces ${ }^{12}$. Although the described selection process for the control group attempts to maximize the probability the control group be equivalent to the treatment group of roads, we cannot discard the existence of certain time-variant unobservables that can affect our estimates.

\subsection{Data requirements and sources}

The impact evaluation presented in this paper refers to the cohort of interventions defined for 2004 and uses the last two rounds (2004 and 2006) of a specialized household and community-level survey that includes a wide variety of socio-economic, institutional and environmental indicators ${ }^{13,14}$. The survey questionnaires were for the most part the same for the two rounds, and they all were applied in the fourth quarter of the corresponding years, so that consistent comparisons are allowed. The household survey includes information about the characteristics of the dwelling, health and education of all household members,

${ }^{11}$ For the outcomes analyzed in this study, Table 4-Table 12 show treatment-control comparisons at baseline. No significant differences are found there.

12 That was the case, for instance, when a district capital was involved. Recall that treated roads needed to be unpaved so capital of provinces have generally not been directly associated to treatment roads.

${ }^{13}$ The Peruvian RRP also applied a baseline survey in 2000 that would allow the analysis of the impacts of that cohort of interventions, also providing valuable information about the dynamics of the effects of the RRP. That is, we would be able to verify the time lags and sustainability of effects. However, such analysis is postponed for a second stage as a very time consuming effort will be required to generate a consistent panel of the three rounds (2000, 2004 and 2006).

${ }^{14}$ The 2004 round of the survey was applied by the firm Cuánto while the 2006 round was applied by GRADE. Both surveys were done in coordination with the Rural Roads Program as part of the program's impact evaluation strategy. 
farm and non-farm entrepreneurial activities, commercialization channels, etc ${ }^{15}$. The community-level survey is applied to key local informants and includes information about the characteristics of the villages in terms of access to public infrastructure and basic services, distance to nearest markets, and other key public facilities. It also includes characteristics of the roads such as the time required to travel from the initial to the final point of the road by the different means, number of public transportation units that use the roads, the number of months the road remain closed over the past year, number of car accidents, maintenance and operation costs for public transportation units offering services in the road. Also, number of students in primary and secondary schools, number of health services offered by public health facilities, judiciary and police crime records, use of associated roads, among many other variables.

Recall treated and control roads are associated to villages by defining the origin and the end of the road. In the case of small roads or tracks (less than $20 \mathrm{kms}$.), 6 households were randomly selected within each the initial and end villages. In the case of large roads, an extra intermediate village is included in the sample. The sample of 2004 cohort of interventions involved 92 treated road segments in 13 of the poorest departments in the country. At baseline, we interviewed a total of 2,457 households in 387 villages associated

\footnotetext{
${ }^{15}$ See Table 1 and Table 2 below for a list of the main indicators available in all survey rounds.
} 
to treatment and control road segments ${ }^{16}$. In 2006, we were able to re-interview 2,167 of them, that is, we had an attrition rate of $11.8 \%{ }^{17}$.

\subsection{Methodology}

The study uses the double difference estimate to determine the impact of the rural roads program on a wide variety of indicators at the level of the household and the localities involved. A basic regression-based DD estimate can be obtained from the following regression:

$Y_{i j t}=\beta_{0}+\beta_{1} \cdot D_{t}^{A D}+\beta_{2} \cdot D_{j}^{T C}+\beta_{3} \cdot D_{t}^{A D} \cdot D_{j}^{T C}+\varepsilon_{i j t}$

where $Y_{i j t}$ denotes the value of an indicator of interest for household i that resides in village $\mathrm{j}$ at period $\mathrm{t}\left(\mathrm{t}=0\right.$ is the baseline; $\mathrm{t}=1$ is the follow-up survey). $D^{T C}$ is a categorical variable that takes value one if the household resides in a treated village and zero if it resides in a control village. $D^{A D}$ is a categorical variable that takes value one if the observation is from the follow-up survey and zero if it comes from the baseline. Finally, $\varepsilon_{i j t}$ denotes the error term which is assumed to be independent across villages but not necessarily within them ${ }^{18}$.

${ }^{16}$ In 2000, a baseline was established for a sample of 2,000 household associated to the road segments that were treated during 2000-2001. That sample was also followed in the 2004 and 2006 round of surveys.

${ }^{17}$ When a household was not initially identified, the field procedures included asking the neighbors, relatives and community leaders. Although there were a few rejections, most of the missing households corresponded to cases in which the nuclear family had moved outside the province.

${ }^{18}$ Thus, we use the Huber-White covariance matrix estimator to obtain the standard error of our coefficients of interest. 
In that setting, $\beta_{3}$ is the DD estimator of the impact of the program on variable $Y$, and is often referred as an average effect as it refers to all beneficiaries without distinction.

If we identify systematic differences between the treatment and control groups in observable variables, we would need to include some controls in expression (1) to check the robustness of our DD estimate. Furthermore, we cannot assure that there are nonobservables that can establish systematic differences between treatment and control groups, but the double-difference (DD) estimate can help control for any time-invariant systematic non-observable difference by including household fixed effects ${ }^{19}$. Thus, a full version of the average DD estimate can be obtained from the following expression:

$Y_{i j t}=\beta_{0}+\beta_{3} \cdot D_{t}^{A D} \cdot D_{j}^{T C}+\lambda_{t}+v_{i j}+\varepsilon_{i j t}$

where $\lambda_{t}$ and $v_{i j}$ denote the year and household fixed effects, respectively. As we plan to analyze the heterogeneity of the effects depending on the characteristics of the roads and the beneficiary villages, the associated econometric analysis will use the following formulation:

$Y_{i j t}=\beta_{0}+\beta_{3} \cdot D_{t}^{A D} \cdot D_{j}^{T C}+\gamma_{3} \cdot D_{t}^{A D} \cdot D_{j}^{T C} \cdot X_{i j}+\lambda_{t}+v_{i j}+\varepsilon_{i j t}$

where $X$ is another dichotomic variable that takes value 1 if the household or village has the characteristic of interest or concern. In that case, $\beta_{3}$ comes to be the DD estimator of the program's impact for those households or villages that does not have the characteristic

${ }^{19}$ Still, since we do not have a randomized control trial, we cannot discard that some time-variant unobservable effects may bias the DD estimate. One way we could argue against such bias is to show that trends prior to the intervention are similar in treatment and control groups (see Galiani, 
of interest $\mathrm{X}$, and $\beta_{3}+\gamma_{3}$ is the one for those that do have it. The impact evaluation proposed here will pay special attention to differentiated impacts by gender, education, ethnicity and village's size.

An important issue is the implications of the attrition rate on the estimates we report here. Random attrition may restrict the statistical power of a study but is mostly harmless. However, treatment effects can be biased if missing observations are correlated with treatment. In general, if the missing observations correspond to those that would have benefited less from the RPP, then our estimates would be overestimating the treatment effects. The opposite would occur if the missing observations correspond to those that would have benefited most. An interesting point established by Angrist, Bettinger and Kremer (2006) is that if we assume that treatment is never harmful, analyzing observed households will give us a lower bound for the effect of a program. In that regard, understanding the improvement of roads can only be positive, then the estimates we report here would need to be considered as a lower bound for the impacts of the PROVIAS intervention, although our attrition rates are relatively low.

\section{Results}

Table 4-Table 11 present the results obtained for road transitability, income, expenditures, poverty, employment, school attendance and access to health services. In each table, we first report the number of households or individuals involved in the estimation. Next, the

Gertler and Schargrodsky, 2005). That could be done for schooling variables as we have a series of school censuses, but not for most of the variables analyzed here. 
first two numbered columns present the averages for each outcome for the treatment and control groups at baseline, while column (3) reports the difference ${ }^{20}$. Columns (4)-(6) do the same for the follow-up survey. Column (7) reports the DD estimate that result from estimating expression (1) in the previous section, while column (8) reports the DD estimate when controlling for household fixed effects as specified in expression (2). Results are always shown separately for motorized roads and non-motorized tracks as they may play different roles in connecting rural households to basic services.

\subsection{Impacts on transitability of roads}

The first important verification is that the presence of the program generated a significant reduction in the average time required to travel from the start point to the endpoint of the road of reference (Table 4). In the case of the motorized roads, the reduction is of 28 minutes from an initial travel time of 100 minutes. In the case of the non-motorized tracks, the reduction is of 37 minutes from an initial travel time of 173 minutes.

As it was suggested from the discussion in the previous section, it would have been very interesting to measure the effect on the number of months a year the road stays closed as a result of climatic shocks. Unfortunately, such information was only collected for treated roads in the 2004 round so we cannot estimate the DD estimator for such variable. The only thing we can verify is that such blockages were even more problematic in 2006 than in 2004. However, Table 5 also shows that community leaders and household heads

\footnotetext{
${ }^{20}$ Notice that for almost all analyzed outcomes, differences between treatment and control groups are not significant, as it is also the case for the variables reported in Table 3.
} 
tend to report an increased level of satisfaction with rehabilitation work in treated localities. In the case of rehabilitation of motorized roads, community leaders in treated villages reported an adequate work in $81 \%$ of the cases by the follow up survey, up from $62 \%$ at baseline. A similar increased satisfaction is observed among households as they increased the reports of positive benefits out of the rehabilitated road. This increased satisfaction among household heads is also found in the case of non-motorized tracks. Nevertheless, an initially puzzling result was to find that community leaders reported deterioration in the quality of the rehabilitation and maintenance work in non-motorized tracks with the program. However, discussions with PROVIAS officers suggest that such reports may be more connected to dissatisfaction with the unfulfilled expectation for the track to be upgraded to a motorized road, rather than an evaluation of the quality of the rehabilitation performed by the contracted MEMV ${ }^{21}$.

These results are non-trivial for the program. First, the positive results on travel time and in the perception of the quality of the program intervention provide evidence against local capture or corruption of the program's mechanism by maintaining payments to MEMVs despite significant reductions in the quality of the rehabilitation and maintenance. Moreover, considering the age of the program (started in 1995), positive impacts on the 2004 cohort of interventions indicate the program has been resilient to such threats. Second, positive impacts are sustained despite the fact that many local governments have seen their budgets increase during the period with economic growth and progress of the

\footnotetext{
${ }^{21}$ Also, recall that monthly payments to local MEMVs are contingent on a satisfactory report from program supervisors, and consecutive negative reports lead to a cancellation of the contract.
} 
decentralization process. Indeed, the number of other roads associated to treatment and control villages that were treated during the period of observation has been important (Table 4). In the case of motorized roads, for instance, villages associated to treated (control) roads had $0.92(0.73)$ roads rehabilitated during the previous two years at baseline, and that number increased to $1.72(1.57)$ by the follow up survey in $2006^{22}$. Thus, the program positive impacts indicate that the difference with the program would likely go beyond the extra money spent in road rehabilitation and maintenance, emphasizing on the clear incentives provided by the contracts with MEMVs.

In the following sub-sections, we analyze the implications of the improved transitability upon income and expenditure patterns, employment decisions and household human capital investments by type of road.

\subsection{Impacts on labor income, employment, expenditures and poverty}

Table 6 reports the average effects of the Peruvian RRP on household labor income (farm and non-farm), expenditures and poverty. We do not find significant effects in any of these variables. A natural first explanation would be associated to the time variable as two years may not be enough time for changes to materialize ${ }^{23}$. Although markets could become

\footnotetext{
${ }^{22}$ Although, road rehabilitation also increased in control roads, it is clear there is no observed bias in the quantity of rehabilitated roads between treatment and control groups, so that no strong evidence is found for a contamination bias. There could be a difference in the quality of rehabilitation work in favor of treated villages, but such difference would be rightly assigned to the impact of the program if associated to the transmission of the program's methodology to the local governments involved.

${ }^{23}$ Recall that the interventions in the round of treated roads we are analyzing started in 2004 and the follow up survey was done in 2006 (see discussion in section 2).
} 
closer as a result of improved roads, key agents may need time to adjust to new conditions. For instance, for farm income, farmers may take more time to recognize that it has become less convenient for them to sell their crops by the field or adjacent road than in local fairs or regional markets. Even if they already noticed it, it may not be that easy for farmers to break the long-term relationship with local merchants ${ }^{24}$.

However, before going any further trying to explain the absence of these income effects, we may want to explore whether some sub-groups may present some positive impacts. Interventions that enhance productivity of farmers tend to benefit most, or first, those that were better off before the program, as they tend to have all the other conditions required to benefit from improved roads. However, it is also feasible to find a pro-poor bias if the less poor are less constrained by bad roads because they may have other assets to compensate. Indeed, recent studies evaluating rural roads programs in developing countries have reported encouraging pro-poor biases in their impacts. Khandker et. al. (2006), for instance, find that some of the effects of a rural roads program in Bangladesh on household expenditures accrue among the poorest households. Mu and van de Valle (2007) also finds that the impacts of the Vietnamese rural roads project concentrate in the poorer communes of Vietnam. Still, it would be important to check whether this bias works also in the case of the Peruvian RRP, considering the results we are reporting here ought to be considered as

${ }^{24}$ See Escobal (2005) for a discussion of the complexity of the decision process associated to selection of markets by Peruvian rural farmers in Huancavelica. The author argues that local merchants establish more personal relationships with local farmers as they tend to be their first alternative to sell. Such sales provide the farmer with the cash necessary to afford taking chances at more profitable but also further and riskier markets such as local fairs or regional markets. Huancavelica is part of the area targeted by the Peruvian RRP. 
early impacts, and also because of the peculiarities of the Peruvian program with respect to the other cases discussed here, namely that the Peruvian RRP does not include pavement upgrades or building new roads. On the other hand, it does include financing of permanent maintenance of the treated rural roads ${ }^{25}$.

In particular, we first explore these hypotheses by checking for heterogeneous impacts by schooling and ethnicity of the household head, village size and altitude. The analysis by village size may be particularly important in the case of the Peruvian RRP. Fieldwork for the 2006 survey showed that in many cases treated roads were connecting a relatively large village with a very small one, with many other small villages along the road. If one thinks that some of the relatively large villages already have key markets and public services available, then we could expect that larger impacts would concentrate on the smaller villages as they would be the ones for whom transaction costs would reduce most. Table 7 shows that the RRP did have effects on household labor income for households residing in villages above 3,400 meters above sea level for which a motorized road was treated. Households with more educated heads and residing in larger villages (more than 850 inhabitants) also present positive impacts but they fall short of being statistically significant. On the other hand, treated non-motorized tracks show even weaker average effects and more variability, with no specific group presenting any positive significant income effects.

\footnotetext{
${ }^{25}$ Although, the Peruvian RRP already focus in some of the poorest provinces, they likely still hide large inequalities across households and villages.
} 
Table 7 also shows positive and significant income effects for households residing in villages with better initial endowments of productive infrastructure such as electricity, local markets and communications, at least in the case of motorized roads. These results support the argument that the rehabilitation and maintenance or rural roads need to be complemented by key infrastructure to lead to higher income.

The positive changes implied by the RRP are further supported when we observe effects on employments decisions by individuals. Indeed, Table 8 shows that individuals residing in villages associated to treated motorized roads increase in 10 days a year their dedication to waged employment, both agricultural and non-agricultural, and reduce their participation in the family farm as unpaid family worker. These effects are small with respect to total days worked a year by an individual (171), which could explain why it does not lead towards significant increases in household income, but they are indeed important with respect to the time dedicated to waged employment at baseline. On the other hand, non-motorized tracks increase in 16 days a year their dedication to the farm as a nonremunerated family worker. Those 16 days a year represent a $30 \%$ increase from the number of working days they dedicated to this kind of labor at baseline.

In Table 9, we analyze the changes in employment patterns generated by the RRP intervention by age, gender and mother tongue. The switch observed in motorized roads towards wage employment seems to be led by adults in the peak of their productive years; that is, between 25 and 50 years old. At the same time, though, females seem to increase their participation in agricultural jobs while males focus on non-agricultural jobs. Notice that in the case of females, they seem to be abandoning work at the farm where they were 
participating as a non-remunerated family worker. In the case of non-motorized tracks, the opposite switch towards farm work is also concentrated among females. Another important result is that employment effects seem to accrue among individuals reporting quechua or aymara as their mother tongue.

The important gender effects on employment are very relevant, especially in the case of non-motorized tracks, as they were specifically included in the program for their relevance to women. If income effects materialize further later, women may have been economically empowered within the household by the Peruvian RRP as they increase their participation in income-generating activities with respect to their male counterparts ${ }^{26}$.

Thus, employment effects support the hypothesis that economic opportunities may have indeed changed with the RRP, but they are not large enough to imply income effects, except when focusing on households residing in high-altitude villages or with pre-existent endowments of key productive infrastructure, at least in the case of motorized roads. Next, we analyze effects on household investments in the education and health of their members.

\subsection{Impacts on household investments in human capital}

With respect to household investments in human capital, we find a strong school attendance effect for children in villages associated to treated motorized tracks, and in morbidity and use of local health facilities for both types of roads. School attendance effects are clearly

\footnotetext{
${ }^{26}$ Need to mention that women increase their participation in productive activities without affecting the time they dedicate to household chores. We do not report those results here but they can be available from the author upon request.
} 
differentiated by gender and age (Table 10$)^{27}$. Attendance increased about 7 percentage points among older boys (12-18 years old), an important effect considering that attendance by such group at baseline was only 84 percent. Considering the age group, it is possible that this effect may imply that with the program boys are better able to attend secondary school while continuing living within the nuclear family, rather than permanently migrating to a larger city $^{28}$. For the younger girls (6-11 years old), school attendance increased 6 percentage points from an initial $93 \%$ attendance rate for this group at baseline. That is, these young girls are reaching perfect attendance to primary school, eliminating a previously negative gender bias.

Lack of effects on younger boys may not be of concern, considering that the level of attendance of this group was already very high (95\%) at baseline. On the other hand, the lack of effects among older girls is worrisome as this group had the lower level of attendance at baseline, and indicates that gender inequalities are still affecting girls in the higher levels of primary school or at the entrance to high school. If that is the case, it would be useful to identify whether the reason is associated to a lower value parents give to higher education of girls, or if it is explained instead by the higher vulnerability girls face with respect to the level of insecurity when traveling longer distances.

\footnotetext{
${ }^{27}$ The attendance reported here refers to the period prior to the survey, and not the current one. Luckily, ENAHO has both variables. Current attendance is much lower at around $50 \%$ for high school level students, but the reports on attendance in the previous period in ENAHO are similar to those reported here.

${ }^{28}$ This hypothesis will be further evaluated with the individual migration data that has not been included in this version of the study.
} 
Finally, Table 11 reports the impact of the Peruvian RRP on morbidity and use of health services by adults and children under five. We find a reduction in the incidence of illnesses and accidents in the four weeks prior to the date of the survey, especially for children under five and in the villages with treated motorized roads. In this case, the morbidity rate falls almost 4 percentage points among all members, but the reduction is almost 9 percentage points when looking only at children under five. The effect on the use of health services (consultations) is also negative which is somewhat puzzling. An explanation could be that improved rural roads may be helping the health system reach better the population from remote areas not by attending them when sick but rather by providing them with useful health information that helps them prevent the illness events and the need for consultations at the health center. Notice that the consultation effect is also larger for children under five, and in that case we also need to consider that more accessible health facilities help them reach children with nutritional supplements.. Such hypothesis is indeed consistent with the finding that households with children under five in these localities report having benefited more (6-8 percentage points) from early childhood development programs, and considering that most of the work of the corresponding nutritional and health programs is made off the health post or center (see Table 12).

On the other hand, a somewhat puzzling result is found among those that were treated through non-motorized tracks, as the use of consultations at health facilities for children under five drops by 12 percentage points, even though the reduction in morbidity is not found statistically significant. However, we should be careful with these results as the 
sample size for children under five in these localities is rather small, something that is also true for the educational outcomes reported in Table 10 (see Table 13)

\section{Summary and discussion}

We studied here the early impacts of a rural roads program that is based on an institutional innovation characterized by the contracting of private local firms for the rehabilitation and maintenance of rural roads with local supervision by community leaders setting incentives that favour prevention activities and a sustainable and timely maintenance of rural roads. We find that this institutional innovation, promoted by the PROVIAS DESCENTRALIZADO of the Ministry of Transport and Communication, quickly improved road transitability which in turn led to significant changes in employment patterns and increased investments in education and health. Income effects are not significant on average, but they appear strong for certain groups, especially in villages with pre-existent endowments of key productive infrastructure. These results, though, are concentrated on interventions in motorized roads, although there are significant changes in employment patterns in the case of non-motorized tracks that seem to indicate an increased participation of women in farm activities.

The impacts on road transitability are positive for the Peruvian RRP, and more generally, for the contracting of local private firms for the rehabilitation and maintenance of rural roads in developing countries. Considering that this study focuses on the cohort of interventions that started in 2004, nine years after the beginning of the program, the positive effects indicate that the intervention has been able to control local capture and 
corruption threats. Although it may still be the case that some money be deviated and or that some special families benefit more from employment by local maintenance firms, it seems that the output-based contracts have helped the program to still present improvements in road transitability after almost a decade of interventions.

On the other hand, observed income effects support the notion that road improvements need to be complemented with other key infrastructure, although it is still possible that more time may be needed for income effects to spread to other villages, considering that the follow up survey we analyze here was done only two years after the beginning of the intervention. Indeed, employment changes on all treated households would support the idea that important changes in economic conditions already occurred with road improvements, although they may take more time to materialize in less endowed environments.

Also, the differences in employment opportunities by type of road indicate they play different roles in connecting rural people to key markets. Motorized roads seem to be playing the more recognized role of connecting rural households to larger cities where product and job markets are more developed and schools and health facilities are available. Non-motorized tracks, on the other hand, play a more important role in mobilizing individuals from their houses to the farm fields, especially for adult women. These changes are particularly stronger for women who increase their participation in economic activities, which likely empower them within the household. The inclusion of treatments to nonmotorized tracks is supported as we find the increased participation of women in economic activities at the family farm is particularly stronger in such interventions. 
The Peruvian RRP also had early effects on school attendance and morbidity in the case of treated motorized roads underscoring the importance of this type of interventions for household investments in human capital. The school attendance effects, however, are not found significant for older girls (12-18 years old), for which the attendance problem was more worrisome to begin with, and suggest the need for further interventions to promote gender equity in schooling investments by rural households. The morbidity effects in turn are especially significant for children under five. These results would indicate the need to consider availability of rural roads when analyzing the capacity of the Juntos program to enforce the conditionalities on school attendance and health checkups by mothers and children.

Finally, considering that the analysis presented here is based on a follow up survey applied after only 1-2 years from the beginning of the intervention, it would be important to continue the analysis of this cohort of interventions by the RRP so that we could elucidate whether, for instance, the lack of income effects is because they need more time to show up, or whether complementary interventions are required. More generally, following interventions over time would allow us to explore deeply into the dynamics of the effects of the RRP, that is, which impacts need more time to mature, and also, whether earlier impacts are sustained in time.

\section{Key references}

Ahmed, R. y Hossain, M. (1990). "Developmental Impact of Rural Infrastructure in Bangladesh". Washington D.C.: International Food Policy Research Institute. 
Bardhan, Pranab; Dilip Mookherjee (2006). "Decentralization and accountability in infrastructure delivery in developing countries". Economic Journal 116: 101-127, January.

Benavides, Juan (2003). "Infraestructura y pobreza rural: coordinación de políticas e intervenciones en países de América Latina y el Caribe". Manuscript IADB, Sustainable Development Department, December.

Bertrand, Marianne; E. Duflo; S. Mullainathan (2004). "How Much Should We Trust Differences-in-Differences Estimates?". Quarterly Journal of Economics 119 (1): 249-275, February.

Binswanger, H. P.; S. R. Khandker; M. R. Rosenzweig (1993). "How infrastructure and financial institutions affect agricultural output and investment in India". Journal of Development Economics 41: 337-366.

Escobal, Javier (2005). “¿Cuan complicado es vincularse con los mercados? El caso de los pequeños productores de papa en Huancavelica”. Economía y Sociedad 55, CIES, Marzo.

Escobal, Javier; Marisol Inurritegui; Juan Benavides (2005). "Infraestructura rural: Guías para diseñar intervenciones y lecciones aprendidas de PROVIAS Rural (Perú)". IADB Series of Technical Reports, Sustainable Development Department, February.

Escobal, Javier; Carmen Ponce (2002). "The Benefits of Rural Roads: Enhancing Income Opportunities for the Rural Poor". GRADE Working Paper \# 40, Lima, November.

Fort, Lucia, Aurelio Menéndez (2002). "Making Rural Roads Work for Both Women and Men: The Example of Peru's Rural Roads Program". The World Bank, Promising Approaches to Engendering Development.

Fort, Ricardo; Fernando Aragón (2006). "Impacto de los Caminos Rurales sobre las Estrategias de Obtención de Ingresos de los Hogares". En Iguiñiz, Escobal y Degregori (eds.) SEPIA XI, Perú: El Problema Agrario en Debate, Lima.

Gannon, C.; Z. Liu (1997). "Poverty and Transport”. The World Bank, INU/TWU Series Transport Publications. TWU-30, Washington, D.C.

Hettige, Hemamala (2006). "When do Rural Roads Benefit the Poor and How?: An InDepth Analysis Based on Case Studies". Asian Development Bank, Operations Evaluation Department, Philippines.

Instituto Cuánto (2004). "Evaluación Económica, Social, Ambiental e Institucional del Provias Rural Fase I". Final Report, November.

.......... (2000). "Evaluación económica, social, ambiental e institucional del Programa Caminos Rurales". Final Report.

Jacoby, H. C. (2000). "Access to markets and the benefits of rural roads". Economic Journal 110 (465): 713-737.

Khandker, Shahidur R.; Zaid Bakht; Gayatri B. Koolwal (2006). “The Poverty Impact of Rural Roads: Evidence from Bangladesh". World Bank Policy Research Working Paper \# 3875, April.

Levy, Hernan (2004). "Rural Roads and Poverty Alleviation in Morocco". Banco Mundial, Manuscrito preparado para la conferencia Scaling Up Poverty Reduction: A Global Learning Process, Shanghai, May 25-27. 
Liu, Z. (2000). Economic analysis of a rural basic access road project: the case of Andhra Pradesh, India.: Infrastructure Notes: Transport Sector, (Transport No. RT-5). The World Bank.

Lucas, K., Davis, T., \& Rikard, K. (1996). Agriculture transport assistance program: impact study. Dar es Salaam: Project Number 621-0166. USAID/Tanzania.

MacDonald, Charles L. (2001) "Ecuador: Programa de Infraestructura Rural de Transporte, valuación Económica de los Proyectos de Rehabilitación de Caminos". Development Ideas, INC.

Malmberg Calvo, Christina (1998). “Options for Managing and Financing Rural Transport Infrastructure". World Bank Technical Paper \# 411.

Mu, Ren; D. van de Walle (2007). "Rural Roads and Poor Area Development in Vietnam". World Bank Policy Research Working Paper \# 4340, August.

Olken, Benjamin (2007). "Monitoring Corruption: Evidence from a Field Experiment in Indonesia”. Journal of Political Economy 115 (2): 200-249, April.

Oré, María Teresa (2001). "El impacto socio-cultural del programa caminos de herradura 1995-2000". The World Bank.

Porter, G. (2002). "Living in a walking world: rural mobility and social equity issues in Sub-Saharan Africa". World Development 30 (2): 285.300.

van de Walle, D. (2002). "Choosing Rural Road Investments to Help Reduce Poverty". World Development 30 (4): 575-589, April.

Windle, J.; R. A. Cramb (1996). "Roads, remoteness and rural development: social impacts of rural roads in upland areas of Sarawak Malaysia". Department of Agriculture, University of Queensland, Agricultural Economics Discussion Paper 3/96, Brisbane, Australia.

World Bank (2005). "Infrastructure and the World Bank: A Progress Report". Report presented to the Development Committee Meeting, September 25, Washington DC.

.......... (2004). "World Development Report: Making Services Work for Poor People". Washington DC.

(1995). "Peru Rural Road Rehabilitation and Maintenance Project: Staff Appraisal Report". Infrastructure and Operations Division manuscript. Washington DC, November. 
Table 1: Key indicators available in household and community-level surveys

\begin{tabular}{|c|c|c|}
\hline Indicators & Description of variables & Source ${ }^{a /}$ \\
\hline \multicolumn{3}{|l|}{ Transport } \\
\hline Travel time & Time in minutes needed to go from the initial to the final point of the road & CLS \\
\hline Traffic intensity & $\begin{array}{l}\text { Average number of public and private transportation units using the road, and frequency of } \\
\text { public units }\end{array}$ & CLS \\
\hline Cost of public transportation & Ticket prices for transporting people and cargo & CLS \\
\hline Usability of the road & Number of months the road was closed over the past 12 months & CLS \\
\hline \multicolumn{3}{|l|}{ Access to health and education } \\
\hline Schooling & Maximum level of schooling attained by each individual & HLS \\
\hline School attendance & Proportion of children currently attending school & HLS \\
\hline School accessibility & Means of transport used to go to school and travel time & HLS \\
\hline School availability in the locality & Number of schools available in the locality, by level & CLS \\
\hline Illness & Number of days individuals were sick/disabled, incidence of diarrhea among children & HLS \\
\hline \multirow[t]{2}{*}{ Use of health care } & Number of individuals that consulted with doctors & HLS \\
\hline & Pregnancies with birth control consultancies, institutional births over the last two years & HLS \\
\hline Accessibility to health care & Means of transport used to go to the nearest health facility and travel time & HLS \\
\hline Availability of health facilities & Number of health facilities available in the locality, by level & CLS \\
\hline \multicolumn{3}{|l|}{ Access to other services } \\
\hline Public telephone & Availability of public phone in the locality & CLS \\
\hline Internet & Availability of internet in the locality & CLS \\
\hline Radio & Availability of radio in the locality & CLS \\
\hline TV signal & Availability of public TV signal in the locality & CLS \\
\hline \multicolumn{3}{|l|}{ Income and employment } \\
\hline Income & Total monthly labor income, by individual and household & HLS \\
\hline Diversification & Proportion of income coming from agricultural, livestock and non-agricultural activities & HLS \\
\hline Wages & Average agricultural and non-agricultural wages for unskilled labor in the locality & HLS \\
\hline Time use & Time dedicated to domestic activities, by age and gender & HLS \\
\hline
\end{tabular}


Table 2: Key indicators available in household and community-level surveys (... continue)

\begin{tabular}{|c|c|c|}
\hline Indicators & Description of variables & Source \\
\hline \multicolumn{3}{|l|}{ Productive activities } \\
\hline Agricultural land & Size of the plots owned and managed by household members & HLS \\
\hline Land use intensity & Land cultivated by household members & HLS \\
\hline Productivity & Yields of main products and value added per hectare & HLS \\
\hline Livestock & Number of heads by type of animal & HLS \\
\hline Productive assets & Number and value of key equipment and machinery & HLS \\
\hline Trade & Proportion of production destined to the local and regional markets & HLS \\
\hline Market accessibility & Means of transport used to go to the main market (local fair) and travel time & HLS \\
\hline Access to agricultural services & Number of households with access to credit and technical assistance & HLS \\
\hline \multicolumn{3}{|l|}{ Expenditures and poverty } \\
\hline Household expenditures & Total per capita monthly expenditures & HLS \\
\hline Poverty rate & Proportion of households with expenditures under the poverty and extreme poverty lines & HLS \\
\hline Unmet basic needs & $\begin{array}{l}\text { Proportion of households without at least one of the basic needs unmet (treated water, sewage, type of } \\
\text { roof, children in school age not attending school, large dependency ratio) }\end{array}$ & HLS \\
\hline \multicolumn{3}{|c|}{ e } \\
\hline Migration & Number of permanent and temporary migrants and immigrants & HLS \\
\hline Social organizations & Number of social organizations in the locality & CLS \\
\hline Presence of public programs & $\begin{array}{l}\text { number of public programs that operated in the locality over the past two years, and number of } \\
\text { beneficiaries in the locality }\end{array}$ & HLS \\
\hline Participation & Number of households with individuals that are active members of local social organizations & HLS \\
\hline \multicolumn{3}{|l|}{ Opinion of the program } \\
\hline Performance of the program & Perception of the quality of rehabilitation and maintenance of roads & CLS \\
\hline Impact & Perception of the types of benefits brought by the rehabilitation and maintenance of the road & HLS / CLS \\
\hline Distribution of benefits & Proportion of households that report having benefited with the rehabilitation and maintenance of road & HLS \\
\hline
\end{tabular}

CLS - community-level survey; HLS - household level survey 
Table 3: Pre-treatment differences for 2004 cohort

\begin{tabular}{|c|c|c|c|c|c|}
\hline Variables & Control & Treatment & Difference & \multicolumn{2}{|l|}{ T-stat } \\
\hline \multicolumn{6}{|l|}{ Household variables } \\
\hline \multicolumn{6}{|l|}{ Age groups } \\
\hline$[0-8]$ & 26.8 & 28.1 & -1.4 & -1.52 & $*$ \\
\hline$[9-18]$ & 25.1 & 24.5 & 0.6 & 0.70 & \\
\hline [19-35] & 23.5 & 23.5 & 0.0 & -0.05 & \\
\hline older than 36 & 24.7 & 23.9 & 0.8 & 0.92 & \\
\hline \multicolumn{6}{|l|}{ School attainment ( 3 years or older) } \\
\hline None & 15.6 & 15.4 & 0.2 & 0.20 & \\
\hline Pre - school & 8.6 & 9.5 & -0.9 & -1.56 & $*$ \\
\hline Primary & 48.5 & 48.5 & 0.0 & 0.04 & \\
\hline Secondary & 24.1 & 23.7 & 0.4 & 0.46 & \\
\hline Superior & 3.2 & 2.8 & 0.3 & 0.93 & \\
\hline Access to water (\%) & 52.7 & 52.2 & 0.5 & 0.20 & \\
\hline Female head (\%) & 11.1 & 10.9 & 0.2 & 0.15 & \\
\hline Head with indigenous mother tongue (\%) & 62.5 & 60.0 & 2.5 & 1.15 & \\
\hline Per Capita Expenditure (monthly soles) & 87.0 & 91.8 & -4.8 & -1.21 & \\
\hline Per Capita Income (monthly soles) & 91.1 & 92.3 & -1.3 & -0.24 & \\
\hline \multicolumn{6}{|l|}{ Poverty } \\
\hline Extreme $(\%)$ & 51.8 & 50.5 & 1.3 & 0.57 & \\
\hline No extreme $(\%)$ & 30.4 & 30.4 & 0.0 & 0.02 & \\
\hline \multicolumn{6}{|l|}{ Village level variables } \\
\hline Population size (\# individuals) & 874.7 & 1023.4 & -148.7 & -0.76 & \\
\hline Altitude (meters above sea level) & 2722.6 & 2799.0 & -76.4 & -0.55 & \\
\hline
\end{tabular}

Source: 2004 Household and Community-level Baseline Surveys 
Table 4: Baseline - Follow-up Statistics and Impact of Rural Roads on Transportation

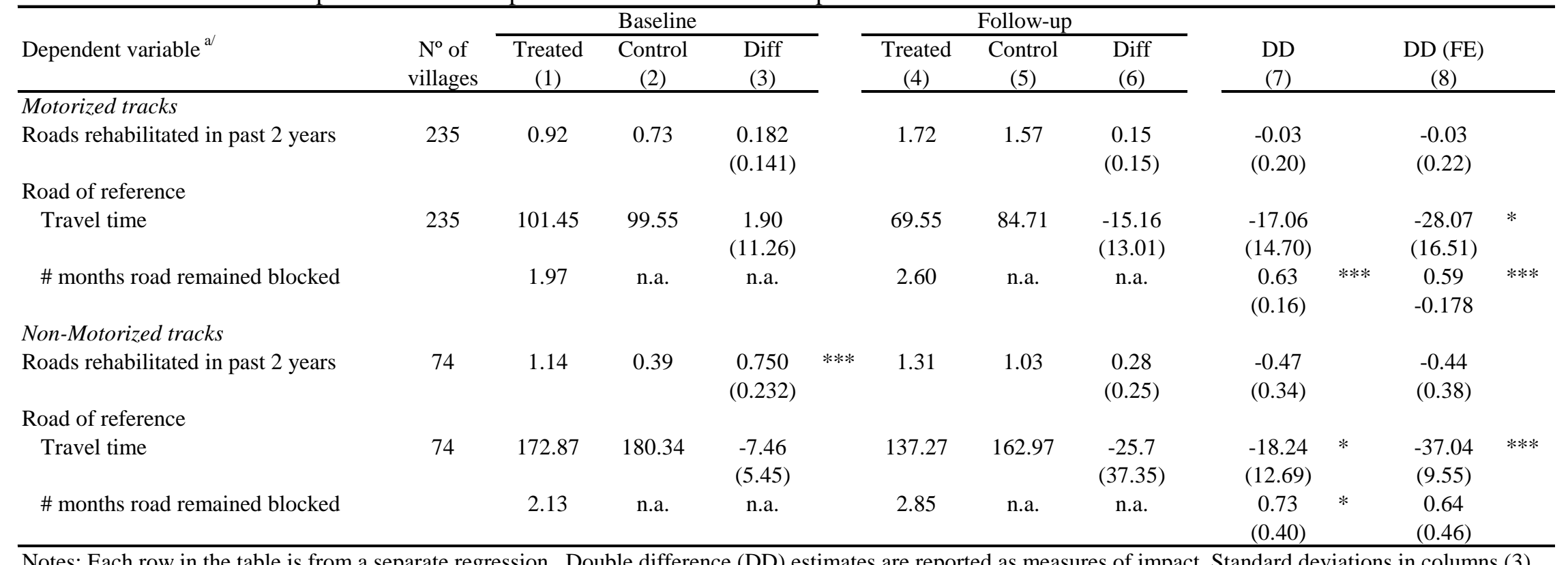

Notes: Each row in the table is from a separate regression. Double difference (DD) estimates are reported as measures of impact. Standard deviations in columns (3), (6) and (7) are adjusted by clustering at household level. Coefficient and standard deviations in column 8 control for household-level fixed effects. * significant at $10 \%$; ** significant at $5 \% ; * * *$ significant at $1 \%$. 
Table 5: Baseline - Follow-up Statistics and Impact of Rural Roads on Transportation

\begin{tabular}{|c|c|c|c|c|c|c|}
\hline \multirow[b]{2}{*}{ Variables } & \multicolumn{3}{|c|}{ Motorized roads } & \multicolumn{3}{|c|}{ Non-motorized tracks } \\
\hline & 2004 & 2006 & & 2004 & 2006 & \\
\hline \multicolumn{7}{|c|}{ Perception of quality of intervention by community leaders } \\
\hline Rehabilitation (=1 if considered adequate) & 62.1 & 80.6 & $* * *$ & 84.1 & 60.0 & $* *$ \\
\hline Maintenance (=1 if considered adequate) & 67.9 & 75.0 & & 70.5 & 47.1 & $* *$ \\
\hline \multicolumn{7}{|l|}{ Perception of quality of intervention by households } \\
\hline Both (=1 if hh benefited from road intervention') & 60.1 & 73.9 & $* * *$ & 47.4 & 65.0 & $* * *$ \\
\hline \multicolumn{7}{|l|}{ Reasons } \\
\hline \multicolumn{7}{|l|}{ Improved access to: } \\
\hline Health care & 48.9 & 64.2 & $* * *$ & 33.3 & 63.2 & $* * *$ \\
\hline Schools & 38.1 & 57.3 & $* * *$ & 21.8 & 54.2 & $* * *$ \\
\hline Markets & 85.1 & 69.3 & $* * *$ & 74.4 & 65.3 & \\
\hline Job opportunities & 40.6 & 57.3 & $* * *$ & 14.1 & 56.3 & $* * *$ \\
\hline Reduced prices of processed goods & 21.1 & 30.0 & $* * *$ & 5.1 & 11.1 & \\
\hline Other & 15.8 & 20.4 & & 20.5 & 17.4 & \\
\hline
\end{tabular}

*** significant at $0.01, * *$ significant at $0.05, *$ significant at 0.1 . 
Table 6: Baseline - Follow-up Statistics and Impact of Rural Roads on Household Labor Income, Expenditures and Poverty

\begin{tabular}{|c|c|c|c|c|c|c|c|c|c|c|}
\hline \multirow[b]{2}{*}{ Dependent variable ${ }^{a /}$} & \multicolumn{3}{|c|}{ Baseline } & & \multicolumn{3}{|c|}{ Follow-up } & & \multirow[b]{2}{*}{$\begin{array}{l}\text { DD } \\
\text { (7) }\end{array}$} & \multirow[b]{2}{*}{$\begin{array}{c}\mathrm{DD}(\mathrm{FE}) \\
(8) \\
\end{array}$} \\
\hline & $\begin{array}{c}\text { Treated } \\
\text { (1) }\end{array}$ & $\begin{array}{c}\text { Control } \\
\text { (2) }\end{array}$ & $\begin{array}{l}\text { Diff } \\
(3)\end{array}$ & & $\begin{array}{c}\text { Treated } \\
\text { (4) }\end{array}$ & $\begin{array}{c}\text { Control } \\
\text { (5) }\end{array}$ & $\begin{array}{c}\text { Diff } \\
\text { (6) }\end{array}$ & & & \\
\hline \multicolumn{11}{|l|}{ Motorized roads } \\
\hline Household monthly income & 358.31 & 365.17 & $\begin{array}{c}-6.87 \\
(18.51)\end{array}$ & & 339.62 & 340.07 & $\begin{array}{l}-0.45 \\
18.55\end{array}$ & & $\begin{array}{c}6.42 \\
(19.36)\end{array}$ & $\begin{array}{c}6.18 \\
(19.63)\end{array}$ \\
\hline Household monthly expenditure & 407.01 & 388.55 & $\begin{array}{c}18.47 \\
(24.49)\end{array}$ & & 443.82 & 427.98 & $\begin{array}{l}15.84 \\
24.49\end{array}$ & & $\begin{array}{c}-2.63 \\
(29.51)\end{array}$ & $\begin{array}{c}-2.63 \\
(29.51)\end{array}$ \\
\hline \multicolumn{11}{|l|}{ Poverty rate } \\
\hline Extreme & 61.25 & 59.55 & $\begin{array}{c}1.69 \\
(2.52)\end{array}$ & & 62.80 & 65.62 & $\begin{array}{l}-2.82 \\
2.54\end{array}$ & & $\begin{array}{l}-4.51 \\
(3.04)\end{array}$ & $\begin{array}{l}-4.91 \\
(3.07)\end{array}$ \\
\hline No extreme & 20.04 & 23.41 & $\begin{array}{l}-3.38 \\
(2.04)\end{array}$ & $*$ & 16.18 & 16.20 & $\begin{array}{l}-0.02 \\
2.05\end{array}$ & & $\begin{array}{c}3.36 \\
(2.81)\end{array}$ & $\begin{array}{c}3.68 \\
(2.85)\end{array}$ \\
\hline Non-poor & 18.70 & 17.06 & $\begin{array}{l}1.65 \\
(2.04)\end{array}$ & & 20.99 & 18.26 & $\begin{array}{l}2.73 \\
2.05\end{array}$ & & $\begin{array}{c}1.08 \\
(2.39)\end{array}$ & $\begin{array}{c}1.24 \\
(2.44)\end{array}$ \\
\hline \multicolumn{11}{|l|}{ Non-Motorized tracks } \\
\hline Household monthly income & 322.06 & 330.81 & $\begin{array}{c}-8.76 \\
(27.96)\end{array}$ & & 291.14 & 262.46 & $\begin{array}{l}28.67 \\
28.09\end{array}$ & & $\begin{array}{c}37.43 \\
(32.59)\end{array}$ & $\begin{array}{c}31.86 \\
(32.97)\end{array}$ \\
\hline Household monthly expenditure & 372.62 & 371.45 & $\begin{array}{c}1.18 \\
(37.19)\end{array}$ & & 393.15 & 349.08 & $\begin{array}{l}44.07 \\
37.19\end{array}$ & & $\begin{array}{c}42.90 \\
(47.29)\end{array}$ & $\begin{array}{c}42.90 \\
(47.29)\end{array}$ \\
\hline \multicolumn{11}{|l|}{ Poverty rate } \\
\hline Extreme & 62.58 & 58.71 & $\begin{array}{c}3.87 \\
(4.42)\end{array}$ & & 69.79 & 69.03 & $\begin{array}{l}0.76 \\
4.43\end{array}$ & & $\begin{array}{l}-3.11 \\
(5.82)\end{array}$ & $\begin{array}{l}-2.26 \\
(5.88)\end{array}$ \\
\hline No extreme & 20.43 & 24.03 & $\begin{array}{l}-3.60 \\
(3.65)\end{array}$ & & 12.99 & 19.57 & $\begin{array}{l}-6.58 \\
3.66\end{array}$ & $*$ & $\begin{array}{l}-2.98 \\
(5.17)\end{array}$ & $\begin{array}{l}-2.63 \\
(5.29)\end{array}$ \\
\hline Non-poor & 16.97 & 17.20 & $\begin{array}{l}-0.23 \\
(3.38)\end{array}$ & & 17.26 & 11.51 & $\begin{array}{l}5.76 \\
3.39\end{array}$ & $*$ & $\begin{array}{c}5.99 \\
(4.35)\end{array}$ & $\begin{array}{c}4.89 \\
(4.41)\end{array}$ \\
\hline
\end{tabular}

at household level. Coefficient and standard deviations in column (8) control for household-level fixed effects. * significant at $10 \%$; ** significant at $5 \%$; *** significant at $1 \%$. 
Table 7: Heterogeneities in the Impact of the RRP: Household Labor Income

\begin{tabular}{|c|c|c|c|c|c|c|c|}
\hline & \multirow[b]{2}{*}{$\begin{array}{c}\mathrm{N}^{\circ} \text { of } \\
\text { households }\end{array}$} & \multicolumn{3}{|c|}{ Motorized roads } & \multirow[b]{2}{*}{$\begin{array}{c}\mathrm{N}^{\circ} \text { of } \\
\text { households }\end{array}$} & \multicolumn{2}{|c|}{ Non-motorized tracks } \\
\hline & & $\begin{array}{c}\text { Treated at } \\
\text { baseline }\end{array}$ & $\mathrm{DD}(\mathrm{FE})$ & & & $\begin{array}{c}\text { Treated at } \\
\text { baseline }\end{array}$ & DD (FE) \\
\hline Base Model & 1493 & 358.31 & $\begin{array}{c}6.18 \\
(19.63)\end{array}$ & & 470 & 322.06 & $\begin{array}{c}31.86 \\
(32.97)\end{array}$ \\
\hline \multicolumn{8}{|c|}{ Household head's schooling } \\
\hline Lower & 1908 & 308.40 & $\begin{array}{c}-8.25 \\
(24.45)\end{array}$ & & 599 & 306.99 & $\begin{array}{c}40.90 \\
(41.13)\end{array}$ \\
\hline Higher & 1070 & 433.57 & $\begin{array}{c}32.01 \\
(32.93)\end{array}$ & & 336 & 344.05 & $\begin{array}{c}15.60 \\
(55.43)\end{array}$ \\
\hline \multicolumn{8}{|l|}{ Village size } \\
\hline Small & 500 & 347.00 & $\begin{array}{c}35.82 \\
(34.42)\end{array}$ & & 187 & 312.13 & $\begin{array}{c}6.37 \\
(52.71)\end{array}$ \\
\hline Medium & 472 & 357.32 & $\begin{array}{l}-14.13 \\
(35.57)\end{array}$ & & 126 & 298.66 & $\begin{array}{c}62.09 \\
(66.02)\end{array}$ \\
\hline Large & 337 & 375.45 & $\begin{array}{c}47.72 \\
(41.45)\end{array}$ & & 107 & 413.73 & $\begin{array}{l}-79.08 \\
(71.45)\end{array}$ \\
\hline \multicolumn{8}{|l|}{ Altitude } \\
\hline Low & 393 & 347.40 & $\begin{array}{l}-34.26 \\
(38.16)\end{array}$ & & 87 & 265.88 & $\begin{array}{c}65.52 \\
(78.36)\end{array}$ \\
\hline Medium & 399 & 384.28 & $\begin{array}{c}21.97 \\
(37.65)\end{array}$ & & 120 & 368.37 & $\begin{array}{c}-8.77 \\
(68.86)\end{array}$ \\
\hline High & 441 & 311.55 & $\begin{array}{c}78.40 \\
(35.69)\end{array}$ & $* *$ & 169 & 326.27 & $\begin{array}{c}2.99 \\
(57.53)\end{array}$ \\
\hline \multicolumn{8}{|l|}{ Infrastructure } \\
\hline \multicolumn{8}{|c|}{ Electric network and/or street lighting } \\
\hline Without & 748 & 348.06 & $\begin{array}{c}-5.59 \\
(27.68)\end{array}$ & & 208 & 328.60 & $\begin{array}{c}-7.03 \\
(50.33)\end{array}$ \\
\hline With & 561 & 371.88 & $\begin{array}{c}64.02 \\
(32.20)\end{array}$ & $* *$ & 212 & 351.74 & $\begin{array}{c}8.33 \\
(50.04)\end{array}$ \\
\hline \multicolumn{8}{|c|}{ Local market } \\
\hline Without & 1195 & 359.95 & $\begin{array}{c}0.91 \\
(21.75)\end{array}$ & & 390 & 343.60 & $\begin{array}{c}22.59 \\
(36.68)\end{array}$ \\
\hline With & 110 & 348.25 & $\begin{array}{l}269.88 \\
(72.38)\end{array}$ & $* * *$ & 30 & 241.52 & $\begin{array}{c}-227.67 \\
(142.03)\end{array}$ \\
\hline \multicolumn{8}{|c|}{ Public telephone } \\
\hline Without & 683 & 355.75 & $\begin{array}{c}2.56 \\
(28.75)\end{array}$ & & 261 & 307.00 & $\begin{array}{c}13.65 \\
(45.06)\end{array}$ \\
\hline With & 626 & 362.34 & $\begin{array}{c}50.53 \\
(30.49)\end{array}$ & $*$ & 159 & 374.77 & $\begin{array}{l}-31.68 \\
(60.02)\end{array}$ \\
\hline \multicolumn{8}{|c|}{ Institutional presence } \\
\hline \multicolumn{8}{|c|}{ Technical Assistance } \\
\hline Without & 804 & 355.20 & $\begin{array}{c}45.17 \\
(26.78)\end{array}$ & $*$ & 328 & 335.18 & $\begin{array}{c}4.21 \\
(40.17)\end{array}$ \\
\hline With & 505 & 364.46 & $\begin{array}{c}-6.42 \\
(33.76)\end{array}$ & & 92 & 350.67 & $\begin{array}{l}-11.37 \\
(77.13)\end{array}$ \\
\hline \multicolumn{8}{|l|}{ Credit } \\
\hline Without & 1134 & 357.02 & $\begin{array}{c}36.39 \\
(22.52)\end{array}$ & & 365 & 334.65 & $\begin{array}{c}4.34 \\
(37.74)\end{array}$ \\
\hline With & 175 & 373.50 & $\begin{array}{c}-62.06 \\
(57.60) \\
\end{array}$ & & 55 & 376.17 & $\begin{array}{c}44.35 \\
(99.14)\end{array}$ \\
\hline
\end{tabular}


Table 8: Baseline - Follow-up Statistics and Impact of Rural Roads on Employment (\%)

\begin{tabular}{|c|c|c|c|c|c|c|c|c|c|c|c|c|c|}
\hline \multirow[b]{2}{*}{ Dependent variable ${ }^{a /}$} & \multirow[b]{2}{*}{$\begin{array}{c}\quad \mathrm{N}^{\mathrm{o}} \text { of } \\
\text { individuals }\end{array}$} & \multicolumn{4}{|c|}{ Baseline } & \multicolumn{4}{|c|}{ Follow-up } & \multirow[b]{2}{*}{$\begin{array}{l}\mathrm{DD} \\
(7) \\
\end{array}$} & & \multirow{2}{*}{\multicolumn{2}{|c|}{$\begin{array}{c}\mathrm{DD}(\mathrm{FE}) \\
(8)\end{array}$}} \\
\hline & & $\begin{array}{c}\text { Treated } \\
\text { (1) }\end{array}$ & $\begin{array}{l}\text { Control } \\
\text { (2) }\end{array}$ & $\begin{array}{l}\text { Diff } \\
\text { (3) }\end{array}$ & & $\begin{array}{c}\text { Treated } \\
\text { (4) }\end{array}$ & $\begin{array}{c}\text { Control } \\
\text { (5) }\end{array}$ & $\begin{array}{c}\text { Diff } \\
(6)\end{array}$ & & & & & \\
\hline \multicolumn{14}{|l|}{ Motorized tracks } \\
\hline Working days per year & 4141 & 170.929 & 170.206 & $\begin{array}{c}0.723 \\
(4.412)\end{array}$ & & 168.105 & 172.134 & $\begin{array}{l}-4.029 \\
(4.417)\end{array}$ & & $\begin{array}{l}-4.752 \\
(5.367)\end{array}$ & & $\begin{array}{l}-4.553 \\
(5.420)\end{array}$ & \\
\hline Wage - Agriculture & 4141 & 7.501 & 6.313 & $\begin{array}{c}1.188 \\
(1.574)\end{array}$ & & 10.506 & 5.712 & $\begin{array}{c}4.793 \\
(1.579)\end{array}$ & $* *$ & $\begin{array}{c}3.606 \\
(1.678)\end{array}$ & $* *$ & $\begin{array}{c}3.808 \\
(1.702)\end{array}$ & $* *$ \\
\hline Wage - No agriculture & 4141 & 10.044 & 10.883 & $\begin{array}{l}-0.839 \\
(2.011)\end{array}$ & & 16.108 & 11.397 & $\begin{array}{l}4.710 \\
(2.017)\end{array}$ & $* *$ & $\begin{array}{c}5.549 \\
(2.213)\end{array}$ & $* *$ & $\begin{array}{c}5.683 \\
(2.244)\end{array}$ & $* *$ \\
\hline Non wage - Agriculture & 4141 & 74.869 & 77.989 & $\begin{array}{l}-3.120 \\
(3.777)\end{array}$ & & 75.625 & 78.078 & $\begin{array}{l}-2.453 \\
(3.781)\end{array}$ & & $\begin{array}{c}0.667 \\
(5.342)\end{array}$ & & $\begin{array}{l}-0.539 \\
(5.436)\end{array}$ & \\
\hline Non wage - No Agriculture & 4141 & 23.776 & 20.495 & $\begin{array}{c}3.281 \\
(3.062)\end{array}$ & & 22.810 & 21.542 & $\begin{array}{l}1.268 \\
(3.072)\end{array}$ & & $\begin{array}{l}-2.014 \\
(3.275)\end{array}$ & & $\begin{array}{l}-2.036 \\
(3.320)\end{array}$ & \\
\hline Unpaid family worker - Agriculture & 4141 & 50.991 & 50.942 & $\begin{array}{c}0.049 \\
(2.944)\end{array}$ & & 37.773 & 47.895 & $\begin{array}{l}-10.122 \\
(2.950)\end{array}$ & $* * *$ & $\begin{array}{c}-10.171 \\
(4.024)\end{array}$ & $* *$ & $\begin{array}{l}-8.986 \\
(4.026)\end{array}$ & $* *$ \\
\hline Unpaid family worker - No Agriculture & 4141 & 2.754 & 2.368 & $\begin{array}{c}0.385 \\
(1.189)\end{array}$ & & 4.630 & 6.524 & $\begin{array}{l}-1.894 \\
(1.193)\end{array}$ & & $\begin{array}{l}-2.280 \\
(1.523)\end{array}$ & & $\begin{array}{l}-2.527 \\
(1.539)\end{array}$ & \\
\hline \multicolumn{14}{|l|}{ Non-Motorized tracks } \\
\hline Working days per year & 1322 & 177.461 & 176.311 & $\begin{array}{c}1.149 \\
(7.556)\end{array}$ & & 179.608 & 167.201 & $\begin{array}{l}12.408 \\
(7.536)\end{array}$ & $*$ & $\begin{array}{l}11.258 \\
(9.680)\end{array}$ & & $\begin{array}{l}10.141 \\
(9.781)\end{array}$ & \\
\hline Wage - Agriculture & 1322 & 1.996 & 4.377 & $\begin{array}{l}-2.380 \\
(1.802)\end{array}$ & & 4.118 & 5.425 & $\begin{array}{l}-1.307 \\
(1.795)\end{array}$ & & $\begin{array}{c}1.074 \\
(2.431)\end{array}$ & & $\begin{array}{c}1.383 \\
(2.457)\end{array}$ & \\
\hline Wage - No agriculture & 1322 & 8.976 & 7.978 & $\begin{array}{c}0.998 \\
(3.191)\end{array}$ & & 9.858 & 13.874 & $\begin{array}{l}-4.016 \\
(3.190)\end{array}$ & & $\begin{array}{l}-5.014 \\
(3.567)\end{array}$ & & $\begin{array}{l}-4.994 \\
(3.633)\end{array}$ & \\
\hline Non wage - Agriculture & 1322 & 92.564 & 92.491 & $\begin{array}{c}0.072 \\
(7.275)\end{array}$ & & 89.580 & 89.679 & $\begin{array}{l}-0.099 \\
(7.234)\end{array}$ & & $\begin{array}{c}-0.171 \\
(10.260)\end{array}$ & & $\begin{array}{c}1.584 \\
(10.544)\end{array}$ & \\
\hline Non wage - No Agriculture & 1322 & 16.713 & 9.898 & $\begin{array}{c}6.815 \\
(3.854)\end{array}$ & $*$ & 17.582 & 10.571 & $\begin{array}{c}7.011 \\
(3.848)\end{array}$ & $*$ & $\begin{array}{c}0.197 \\
(4.705)\end{array}$ & & $\begin{array}{l}-1.373 \\
(4.747)\end{array}$ & \\
\hline Unpaid family worker - Agriculture & 1322 & 53.783 & 58.624 & $\begin{array}{l}-4.841 \\
(5.472)\end{array}$ & & 53.795 & 41.515 & $\begin{array}{l}12.279 \\
(5.448)\end{array}$ & $* *$ & $\begin{array}{l}17.120 \\
(7.500)\end{array}$ & $* *$ & $\begin{array}{l}16.393 \\
(7.511)\end{array}$ & $* *$ \\
\hline Unpaid family worker - No Agriculture & 1322 & 2.470 & 1.526 & $\begin{array}{c}0.944 \\
(1.772)\end{array}$ & & 3.752 & 4.742 & $\begin{array}{l}-0.990 \\
(1.762)\end{array}$ & & $\begin{array}{l}-1.935 \\
(2.499)\end{array}$ & & $\begin{array}{l}-2.701 \\
(2.530)\end{array}$ & \\
\hline
\end{tabular}
control for household-level fixed effects. Double difference estimates are reported as measures of impact. * significant at $10 \%$; ** significant at $5 \%$; *** significant at $1 \%$. 
Table 9: Heterogeneities in the Impact of the RRP - Employment

\begin{tabular}{|c|c|c|c|c|c|c|c|c|c|}
\hline \multirow[b]{2}{*}{ Dependent variable ${ }^{\mathrm{a} /}$} & \multirow[b]{2}{*}{$\begin{array}{l}\text { Base model } \\
\text { (1) }\end{array}$} & \multicolumn{3}{|c|}{ Age } & \multicolumn{2}{|c|}{ Gender } & \multicolumn{3}{|c|}{ Mother Tongue } \\
\hline & & $\begin{array}{l}\text { Younger } \\
\text { (2) }\end{array}$ & $\begin{array}{l}\text { Middle } \\
\text { (3) }\end{array}$ & $\begin{array}{l}\text { Older } \\
(4)\end{array}$ & $\begin{array}{l}\text { Female } \\
(5)\end{array}$ & $\begin{array}{l}\text { Male } \\
(6)\end{array}$ & $\begin{array}{c}\text { Quechua/Aymara } \\
\text { (7) }\end{array}$ & $\begin{array}{c}\text { Spanish } \\
(8)\end{array}$ & \\
\hline Motorized tracks & & & & & & & & & \\
\hline Working days per year & $\begin{array}{r}-4.55 \\
(5.42)\end{array}$ & $\begin{array}{r}-15.55 \\
(9.78)\end{array}$ & $\begin{array}{r}5.79 \\
(7.24)\end{array}$ & $\begin{array}{l}-12.43 \\
(11.81)\end{array}$ & $\begin{array}{r}-9.61 \\
-(7.43)\end{array}$ & $\begin{array}{r}3.33 \\
(7.33)\end{array}$ & $\begin{array}{r}-7.56 \\
(6.86)\end{array}$ & $\begin{array}{r}0.83 \\
(8.85)\end{array}$ & \\
\hline Wage - Agriculture & $\begin{array}{l}3.81 * * \\
(1.70)\end{array}$ & $\begin{array}{r}0.69 \\
(3.25)\end{array}$ & $\begin{array}{l}5.53 * * \\
(2.40)\end{array}$ & $\begin{array}{r}3.85 \\
(3.92)\end{array}$ & $\begin{array}{r}4.06 * \\
-(2.41)\end{array}$ & $\begin{array}{r}3.53 \\
(2.38)\end{array}$ & $\begin{array}{r}2.59 \\
(2.15)\end{array}$ & $\begin{array}{r}5.79 \\
(2.78)\end{array}$ & ** \\
\hline Wage - No agriculture & $\begin{array}{l}5.68 * * \\
(2.24)\end{array}$ & $\begin{array}{r}4.14 \\
(4.27)\end{array}$ & $\begin{array}{l}7.07 * * \\
(3.14)\end{array}$ & $\begin{array}{r}4.47 \\
(5.14)\end{array}$ & $\begin{array}{r}3.56 \\
-(3.16)\end{array}$ & $\begin{array}{l}7.98 * * \\
(3.12)\end{array}$ & $\begin{array}{l}6.23 * * \\
(2.84)\end{array}$ & $\begin{array}{r}4.73 \\
(3.66)\end{array}$ & \\
\hline Non wage - Agriculture & $\begin{array}{r}-0.54 \\
(5.44)\end{array}$ & $\begin{array}{r}3.78 \\
(9.82)\end{array}$ & $\begin{array}{r}-3.55 \\
(7.24)\end{array}$ & $\begin{array}{r}0.60 \\
(11.83)\end{array}$ & $\begin{array}{r}2.90 \\
-(6.92)\end{array}$ & $\begin{array}{r}-3.44 \\
(6.84)\end{array}$ & $\begin{array}{r}-1.31 \\
(6.88)\end{array}$ & $\begin{array}{r}1.19 \\
(8.87)\end{array}$ & \\
\hline Non wage - No Agriculture & $\begin{array}{r}-2.04 \\
(3.32)\end{array}$ & $\begin{array}{r}-8.08 \\
(6.30)\end{array}$ & $\begin{array}{r}1.34 \\
(4.64)\end{array}$ & $\begin{array}{r}-3.14 \\
(7.58)\end{array}$ & $\begin{array}{r}-2.91 \\
-(4.72)\end{array}$ & $\begin{array}{r}-0.73 \\
(4.66)\end{array}$ & $\begin{array}{r}-5.09 \\
(4.20)\end{array}$ & $\begin{array}{r}3.12 \\
(5.42)\end{array}$ & \\
\hline Unpaid family worker - Agriculture & $\begin{array}{l}-8.99 * * \\
(4.03)\end{array}$ & $\begin{array}{c}-14.53 * \\
(7.60)\end{array}$ & $\begin{array}{r}-1.16 \\
(5.60)\end{array}$ & $\begin{array}{c}-17.01 * \\
(9.15)\end{array}$ & $\begin{array}{l}-14.45 * * * \\
(5.45)\end{array}$ & $\begin{array}{r}-1.86 \\
(5.38)\end{array}$ & $\begin{array}{r}-7.53 \\
(5.09)\end{array}$ & $\begin{array}{r}-11.46 \\
(6.57)\end{array}$ & $*$ \\
\hline Unpaid family worker - No Agriculture & $\begin{array}{r}-2.53 \\
(1.54)\end{array}$ & $\begin{array}{r}-1.58 \\
(2.94)\end{array}$ & $\begin{array}{r}-3.38 \\
(2.17)\end{array}$ & $\begin{array}{r}-1.75 \\
(3.54)\end{array}$ & $\begin{array}{r}-3.14 \\
-(2.18)\end{array}$ & $\begin{array}{r}-2.00 \\
(2.16)\end{array}$ & $\begin{array}{r}-2.57 \\
(1.95)\end{array}$ & $\begin{array}{r}-2.47 \\
(2.51)\end{array}$ & \\
\hline Non-Motorized tracks & & & & & & & & & \\
\hline Working days per year & $\begin{array}{r}10.14 \\
(9.78)\end{array}$ & $\begin{array}{r}26.03 \\
(17.22)\end{array}$ & $\begin{array}{r}7.56 \\
(13.34)\end{array}$ & $\begin{array}{r}-0.96 \\
(21.49)\end{array}$ & $\begin{array}{l}29.92 * * \\
(13.29)\end{array}$ & $\begin{array}{r}-8.73 \\
(13.22)\end{array}$ & $\begin{array}{r}5.81 \\
(13.21)\end{array}$ & $\begin{array}{r}13.92 \\
(14.62)\end{array}$ & \\
\hline Wage - Agriculture & $\begin{array}{r}1.38 \\
(2.46)\end{array}$ & $\begin{array}{r}2.09 \\
(4.53)\end{array}$ & $\begin{array}{r}0.06 \\
(3.51)\end{array}$ & $\begin{array}{r}4.70 \\
(5.65)\end{array}$ & $\begin{array}{r}1.09 \\
-(3.47)\end{array}$ & $\begin{array}{r}1.87 \\
(3.46)\end{array}$ & $\begin{array}{r}4.63 \\
(3.32)\end{array}$ & $\begin{array}{r}-2.44 \\
(3.67)\end{array}$ & \\
\hline Wage - No agriculture & $\begin{array}{r}-4.99 \\
(3.63)\end{array}$ & $\begin{array}{r}-4.38 \\
(6.69)\end{array}$ & $\begin{array}{r}-4.97 \\
(5.18)\end{array}$ & $\begin{array}{r}-3.54 \\
(8.34)\end{array}$ & $\begin{array}{r}-4.23 \\
(5.10)\end{array}$ & $\begin{array}{r}-5.66 \\
(5.07)\end{array}$ & $\begin{array}{r}-3.94 \\
(4.90)\end{array}$ & $\begin{array}{r}-5.11 \\
(5.43)\end{array}$ & \\
\hline Non wage - Agriculture & $\begin{array}{r}1.58 \\
(10.54)\end{array}$ & $\begin{array}{r}7.34 \\
(18.26)\end{array}$ & $\begin{array}{r}-0.14 \\
(14.14)\end{array}$ & $\begin{array}{r}2.20 \\
(22.77)\end{array}$ & $\begin{array}{r}16.37 \\
-(13.48)\end{array}$ & $\begin{array}{r}-12.77 \\
(13.41)\end{array}$ & $\begin{array}{r}3.25 \\
(14.24)\end{array}$ & $\begin{array}{r}-1.32 \\
(15.77)\end{array}$ & \\
\hline Non wage - No Agriculture & $\begin{array}{r}-1.37 \\
(4.75)\end{array}$ & $\begin{array}{r}0.55 \\
(8.72)\end{array}$ & $\begin{array}{r}-0.31 \\
(6.75)\end{array}$ & $\begin{array}{r}-4.93 \\
(10.87)\end{array}$ & $\begin{array}{r}1.03 \\
-(6.72)\end{array}$ & $\begin{array}{r}-3.79 \\
(6.69)\end{array}$ & $\begin{array}{r}1.48 \\
(6.41)\end{array}$ & $\begin{array}{r}-3.84 \\
(7.09)\end{array}$ & \\
\hline Unpaid family worker - Agriculture & $\begin{array}{l}16.39 * * \\
(7.51)\end{array}$ & $\begin{array}{r}15.83 \\
(13.60)\end{array}$ & $\begin{array}{r}16.02 \\
(10.53)\end{array}$ & $\begin{array}{r}13.73 \\
(16.96)\end{array}$ & $\begin{array}{l}20.46 \text { ** } \\
(10.24)\end{array}$ & $\begin{array}{r}12.59 \\
(10.19)\end{array}$ & $\begin{array}{r}4.11 \\
(10.13)\end{array}$ & $\begin{array}{c}29.29 \\
(11.21)\end{array}$ & *** \\
\hline Unpaid family worker - No Agriculture & $\begin{array}{l}-2.70 \\
(2.53)\end{array}$ & $\begin{array}{r}4.77 \\
(4.66)\end{array}$ & $\begin{array}{r}-3.10 \\
(3.61)\end{array}$ & $\begin{array}{l}-13.07 * * \\
(5.81)\end{array}$ & $\begin{array}{r}-4.65 \\
-(3.58)\end{array}$ & $\begin{array}{r}-0.95 \\
(3.56)\end{array}$ & $\begin{array}{r}-3.72 \\
(3.41)\end{array}$ & $\begin{array}{r}-2.33 \\
(3.78)\end{array}$ & \\
\hline
\end{tabular}
impact. "significant at 10\%, significant at $5 \%$, significant at $1 \%$. Heterogeneous categories are defined as follows. Age: Cohort 1 is for indivuduals younger than 25 years old; Cohort 2 , from 26 to 50 years old; Cohort 3, older than 50. Gender: if the individual is female or male. Village size: Small is for villages with less than 300 inhabitants; Medium, with more than 300 to 850 inhabitants; Large, with more than 850
inhabitants. Altitude: Low is for villages which are 2500 meters above sea level, Medium, between 2500 and 3400 meters above sea level, High, from more than 3400 to 5500 meters above sea level. Mother tongue: if the mother tongue of the household head is quechua/aymara or spanish. 
Table 10: Baseline - Follow-up Statistics and Impact of Rural Roads on School Attendance (\%)

\begin{tabular}{|c|c|c|c|c|c|c|c|c|c|c|c|c|c|}
\hline \multirow[b]{2}{*}{ Dependent variable ${ }^{a /}$} & \multirow[b]{2}{*}{$\begin{array}{c}\mathrm{N}^{\circ} \text { of } \\
\text { individuals }\end{array}$} & \multicolumn{4}{|c|}{ Baseline } & \multicolumn{4}{|c|}{ Follow-up } & \multirow[b]{2}{*}{$\begin{array}{l}\mathrm{DD} \\
\text { (7) }\end{array}$} & \multirow{2}{*}{\multicolumn{3}{|c|}{$\begin{array}{c}\mathrm{DD}(\mathrm{FE}) \\
(8)\end{array}$}} \\
\hline & & $\begin{array}{l}\text { Treated } \\
\text { (1) }\end{array}$ & $\begin{array}{l}\text { Control } \\
\text { (2) }\end{array}$ & $\begin{array}{l}\text { Diff } \\
\text { (3) }\end{array}$ & & $\begin{array}{l}\text { Treated } \\
(4) \\
\end{array}$ & $\begin{array}{c}\text { Control } \\
(5)\end{array}$ & $\begin{array}{l}\text { Diff } \\
(6) \\
\end{array}$ & & & & & \\
\hline Motorized tracks & & & & & & & & & & & & & \\
\hline Males 6-11 years & 711 & 95.435 & 92.597 & $\begin{array}{c}2.837 \\
(2.009)\end{array}$ & & 91.938 & 90.872 & $\begin{array}{l}1.066 \\
(2.027)\end{array}$ & & $\begin{array}{l}-1.772 \\
(2.614)\end{array}$ & & $\begin{array}{l}-3.752 \\
(3.082)\end{array}$ & \\
\hline Males $12-18$ years & 612 & 84.153 & 89.268 & $\begin{array}{l}-5.115 \\
(3.044)\end{array}$ & $*$ & 84.104 & 79.561 & $\begin{array}{c}4.543 \\
(2.921)\end{array}$ & & $\begin{array}{c}9.659 \\
(3.808)\end{array}$ & $* *$ & $\begin{array}{c}7.291 \\
(4.276)\end{array}$ & $*$ \\
\hline Females 6-11 years & 734 & 93.196 & 95.524 & $\begin{array}{l}-2.328 \\
(1.913)\end{array}$ & & 95.180 & 88.719 & $\begin{array}{c}6.462 \\
(1.953)\end{array}$ & $* * *$ & $\begin{array}{c}8.789 \\
(2.459)\end{array}$ & $* * *$ & $\begin{array}{c}6.898 \\
(2.862)\end{array}$ & $* *$ \\
\hline Females $12-18$ years & 521 & 80.628 & 84.530 & $\begin{array}{l}-3.902 \\
(3.319)\end{array}$ & & 84.022 & 85.976 & $\begin{array}{l}-1.954 \\
(3.139)\end{array}$ & & $\begin{array}{c}1.948 \\
(3.696)\end{array}$ & & $\begin{array}{l}-0.222 \\
(4.156)\end{array}$ & \\
\hline Non-Motorized tracks & & & & & & & & & & & & & \\
\hline Males 6-11 years & 232 & 92.936 & 95.637 & $\begin{array}{l}-2.702 \\
(3.704)\end{array}$ & & 83.689 & 92.352 & $\begin{array}{l}-8.662 \\
(3.866)\end{array}$ & $* *$ & $\begin{array}{l}-5.960 \\
(5.275)\end{array}$ & & $\begin{array}{l}-2.751 \\
(6.276)\end{array}$ & \\
\hline Males $12-18$ years & 212 & 83.541 & 91.777 & $\begin{array}{l}-8.236 \\
(5.328)\end{array}$ & & 72.452 & 85.730 & $\begin{array}{l}-13.277 \\
(4.965)\end{array}$ & $* *$ & $\begin{array}{l}-5.041 \\
(6.509)\end{array}$ & & $\begin{array}{l}-6.706 \\
(7.372)\end{array}$ & \\
\hline Females 6-11 years & 222 & 89.290 & 91.215 & $\begin{array}{l}-1.925 \\
(4.331)\end{array}$ & & 85.740 & 89.567 & $\begin{array}{l}-3.827 \\
(4.301)\end{array}$ & & $\begin{array}{l}-1.903 \\
(5.678)\end{array}$ & & $\begin{array}{l}-1.789 \\
(6.592)\end{array}$ & \\
\hline Females $12-18$ years & 172 & 79.579 & 78.880 & $\begin{array}{c}0.699 \\
(6.410)\end{array}$ & & 76.656 & 83.504 & $\begin{array}{l}-6.847 \\
(5.965)\end{array}$ & & $\begin{array}{l}-7.546 \\
(7.247)\end{array}$ & & $\begin{array}{l}-8.741 \\
(8.286)\end{array}$ & \\
\hline
\end{tabular}


Table 11: Baseline - Follow-up Statistics and Impact of Rural Roads on Morbidity and Use of Health Services (\%)

\begin{tabular}{|c|c|c|c|c|c|c|c|c|c|c|c|c|c|}
\hline \multirow[b]{2}{*}{ Dependent variable ${ }^{a /}$} & \multirow[b]{2}{*}{$\begin{array}{c}\mathrm{N}^{\mathrm{a}} \text { of } \\
\text { individuals }\end{array}$} & \multicolumn{4}{|c|}{ Baseline } & \multicolumn{4}{|c|}{ Follow-up } & \multirow{3}{*}{$\begin{array}{l}\text { DD } \\
(7) \\
\end{array}$} & & \multirow{2}{*}{\multicolumn{2}{|c|}{$\begin{array}{c}\mathrm{DD}(\mathrm{FE}) \\
(8)\end{array}$}} \\
\hline & & $\begin{array}{l}\text { Treated } \\
\text { (1) }\end{array}$ & $\begin{array}{c}\text { Control } \\
\text { (2) }\end{array}$ & $\begin{array}{l}\text { Diff } \\
\text { (3) }\end{array}$ & & $\begin{array}{l}\text { Treated } \\
\text { (4) }\end{array}$ & $\begin{array}{c}\text { Control } \\
(5)\end{array}$ & $\begin{array}{c}\text { Diff } \\
\text { (6) }\end{array}$ & & & & & \\
\hline \multicolumn{13}{|l|}{ Motorized tracks } & \\
\hline \multicolumn{14}{|c|}{ Sickness and accidents in last 4 weeks } \\
\hline All household members & 7574 & 38.569 & 35.573 & $\begin{array}{c}2.996 \\
(1.401)\end{array}$ & $* *$ & 30.661 & 31.471 & $\begin{array}{l}-0.811 \\
(1.413)\end{array}$ & & $\begin{array}{l}-3.807 \\
(1.426)\end{array}$ & $* *$ & $\begin{array}{l}-3.724 \\
(1.434)\end{array}$ & $* *$ \\
\hline Children $0-5$ years & 1396 & 47.757 & 42.929 & $\begin{array}{c}4.828 \\
(2.780)\end{array}$ & $*$ & 35.830 & 38.233 & $\begin{array}{l}-2.403 \\
(3.100)\end{array}$ & & $\begin{array}{l}-7.231 \\
(3.685)\end{array}$ & $* *$ & $\begin{array}{l}-8.789 \\
(3.998)\end{array}$ & $* *$ \\
\hline \multicolumn{14}{|c|}{ Attention from a heath professional } \\
\hline All household members & 7574 & 21.441 & 19.804 & $\begin{array}{c}1.637 \\
(1.154)\end{array}$ & & 20.718 & 21.661 & $\begin{array}{l}-0.943 \\
(1.165)\end{array}$ & & $\begin{array}{l}-2.581 \\
(1.246)\end{array}$ & $* *$ & $\begin{array}{l}-2.591 \\
(1.255)\end{array}$ & $* *$ \\
\hline Children $0-5$ years & 1396 & 38.368 & 38.442 & $\begin{array}{c}-0.074 \\
(2.673)\end{array}$ & & 30.063 & 35.271 & $\begin{array}{l}-5.208 \\
(2.990)\end{array}$ & $*$ & $\begin{array}{l}-5.134 \\
(3.659)\end{array}$ & & $\begin{array}{l}-8.078 \\
(3.972)\end{array}$ & $* *$ \\
\hline \multicolumn{14}{|l|}{ Non-Motorized tracks } \\
\hline \multicolumn{14}{|c|}{ Sickness and accidents in last 4 weeks } \\
\hline All household members & 2348 & 32.806 & 34.790 & $\begin{array}{l}-1.984 \\
(2.483)\end{array}$ & & 33.783 & 33.219 & $\begin{array}{c}0.565 \\
(2.478)\end{array}$ & & $\begin{array}{c}2.549 \\
(2.552)\end{array}$ & & $\begin{array}{c}2.141 \\
(2.567)\end{array}$ & \\
\hline Children $0-5$ years & 369 & 46.487 & 36.114 & $\begin{array}{l}10.374 \\
(5.284)\end{array}$ & $* *$ & 33.724 & 35.066 & $\begin{array}{l}-1.342 \\
(5.508)\end{array}$ & & $\begin{array}{l}-11.715 \\
(6.824)\end{array}$ & $*$ & $\begin{array}{l}-7.385 \\
(7.526)\end{array}$ & \\
\hline \multicolumn{14}{|c|}{ Attention from a heath professional } \\
\hline All household members & 2348 & 17.254 & 18.677 & $\begin{array}{l}-1.422 \\
(1.989)\end{array}$ & & 19.933 & 18.406 & $\begin{array}{c}1.526 \\
(1.985)\end{array}$ & & $\begin{array}{c}2.949 \\
(2.109)\end{array}$ & & $\begin{array}{c}2.598 \\
(2.120)\end{array}$ & \\
\hline Children $0-5$ years & 369 & 35.768 & 31.436 & $\begin{array}{c}4.332 \\
(4.999)\end{array}$ & & 22.120 & 30.876 & $\begin{array}{l}-8.756 \\
(5.207)\end{array}$ & $*$ & $\begin{array}{l}-13.087 \\
(6.375)\end{array}$ & $* *$ & $\begin{array}{l}-12.498 \\
(7.008)\end{array}$ & $*$ \\
\hline
\end{tabular}

Notes: Each row in the table is from a separate regression. Double difference (DD) estimates are reported as measures of impact. Standard deviations in columns (3), (6) and (7) are adjusted by clustering at household level. Coefficient and standard deviations in column (8) control for household-level fixed effects. * significant at 10\%; ** significant at 5\%; *** significant at $1 \%$. 
Table 12: Baseline - Follow-up Statistics and Impact of Rural Roads on Access to Social Programs (\%)

\begin{tabular}{|c|c|c|c|c|c|c|c|c|c|c|c|c|}
\hline \multirow[b]{2}{*}{ Dependent variable $^{a /}$} & \multirow[b]{2}{*}{$\begin{array}{c}\mathrm{N}^{\circ} \text { of } \\
\text { households }\end{array}$} & \multicolumn{3}{|c|}{ Baseline } & \multicolumn{4}{|c|}{ Follow-up } & \multirow[b]{2}{*}{$\begin{array}{l}\text { DD } \\
(7)\end{array}$} & \multirow{2}{*}{\multicolumn{3}{|c|}{$\begin{array}{c}\mathrm{DD}(\mathrm{FE}) \\
(8)\end{array}$}} \\
\hline & & $\begin{array}{l}\text { Treated } \\
\text { (1) }\end{array}$ & $\begin{array}{l}\text { Control } \\
\text { (2) }\end{array}$ & $\begin{array}{c}\text { Diff } \\
\text { (3) }\end{array}$ & $\begin{array}{c}\text { Treated } \\
\text { (4) }\end{array}$ & $\begin{array}{c}\text { Control } \\
\text { (5) }\end{array}$ & $\begin{array}{c}\text { Diff } \\
(6)\end{array}$ & & & & & \\
\hline \multicolumn{13}{|l|}{ Motorized tracks } \\
\hline \multicolumn{13}{|l|}{ Social Programs } \\
\hline Food & 1525 & 73.208 & 72.055 & $\begin{array}{c}1.153 \\
(2.402)\end{array}$ & 62.390 & 56.849 & $\begin{array}{c}5.541 \\
(2.402)\end{array}$ & $* *$ & $\begin{array}{c}4.388 \\
(2.695)\end{array}$ & & $\begin{array}{c}4.388 \\
(2.695)\end{array}$ & \\
\hline Education & 1525 & 63.396 & 64.658 & $\begin{array}{l}-1.261 \\
(2.461)\end{array}$ & 65.409 & 62.603 & $\begin{array}{c}2.806 \\
(2.461)\end{array}$ & & $\begin{array}{c}4.067 \\
(2.595)\end{array}$ & & $\begin{array}{c}4.067 \\
(2.595)\end{array}$ & \\
\hline Health & 1525 & 54.843 & 53.288 & $\begin{array}{c}1.555 \\
(2.398)\end{array}$ & 75.849 & 73.425 & $\begin{array}{c}2.424 \\
(2.398)\end{array}$ & & $\begin{array}{c}0.869 \\
(2.852)\end{array}$ & & $\begin{array}{c}0.869 \\
(2.852)\end{array}$ & \\
\hline \multicolumn{13}{|l|}{ ECD1 } \\
\hline All households & 1525 & 57.484 & 54.658 & $\begin{array}{c}2.827 \\
(2.388)\end{array}$ & 76.226 & 73.699 & $\begin{array}{c}2.528 \\
(2.388)\end{array}$ & & $\begin{array}{l}-0.299 \\
(2.834)\end{array}$ & & $\begin{array}{l}-0.299 \\
(2.834)\end{array}$ & \\
\hline Households with children under 6 years & 958 & 79.923 & 81.136 & $\begin{array}{l}-1.214 \\
(2.415)\end{array}$ & 88.996 & 82.273 & $\begin{array}{c}6.723 \\
(2.415)\end{array}$ & $* * *$ & $\begin{array}{c}7.937 \\
(3.353)\end{array}$ & $* *$ & $\begin{array}{c}7.937 \\
(3.353)\end{array}$ & $* *$ \\
\hline \multicolumn{13}{|l|}{ ECD2 } \\
\hline All households & 1525 & 76.730 & 76.027 & $\begin{array}{c}0.702 \\
(2.093)\end{array}$ & 81.761 & 80.548 & $\begin{array}{c}1.213 \\
(2.093)\end{array}$ & & $\begin{array}{c}0.511 \\
(2.442)\end{array}$ & & $\begin{array}{c}0.511 \\
(2.442)\end{array}$ & \\
\hline Households with children under 6 years & 958 & 95.560 & 97.727 & $\begin{array}{c}-2.167 \\
(1.529)\end{array}$ & 93.243 & 89.318 & $\begin{array}{c}3.925 \\
(1.529)\end{array}$ & $* * *$ & $\begin{array}{c}6.092 \\
(2.093)\end{array}$ & $* * *$ & $\begin{array}{c}6.092 \\
(2.093)\end{array}$ & $* * *$ \\
\hline \multicolumn{13}{|l|}{ Non-Motorized tracks } \\
\hline \multicolumn{13}{|l|}{ Social Programs } \\
\hline Food & 478 & 68.619 & 67.364 & $\begin{array}{c}1.255 \\
(4.378)\end{array}$ & 60.251 & 61.088 & $\begin{array}{c}-0.837 \\
(4.378)\end{array}$ & & $\begin{array}{c}-2.092 \\
(4.788)\end{array}$ & & $\begin{array}{c}-2.092 \\
(4.788)\end{array}$ & \\
\hline Education & 478 & 69.874 & 64.854 & $\begin{array}{c}5.021 \\
(4.264)\end{array}$ & 67.782 & 70.293 & $\begin{array}{l}-2.510 \\
(4.264)\end{array}$ & & $\begin{array}{l}-7.531 \\
(4.875)\end{array}$ & & $\begin{array}{l}-7.531 \\
(4.875)\end{array}$ & \\
\hline Health & 478 & 44.351 & 51.046 & $\begin{array}{l}-6.695 \\
(4.297)\end{array}$ & 73.222 & 75.314 & $\begin{array}{c}-2.092 \\
(4.297)\end{array}$ & & $\begin{array}{c}4.603 \\
(5.118)\end{array}$ & & $\begin{array}{c}4.603 \\
(5.118)\end{array}$ & \\
\hline \multicolumn{13}{|l|}{ ECD1 } \\
\hline All households & 478 & 46.025 & 51.046 & $\begin{array}{l}-5.021 \\
(4.280)\end{array}$ & 74.059 & 76.151 & $\begin{array}{l}-2.092 \\
(4.280)\end{array}$ & & $\begin{array}{c}2.929 \\
(5.086)\end{array}$ & & $\begin{array}{c}2.929 \\
(5.086)\end{array}$ & \\
\hline Households with children under 6 years & 261 & 73.134 & 79.528 & $\begin{array}{l}-6.393 \\
(4.721)\end{array}$ & 82.836 & 92.126 & $\begin{array}{l}-9.290 \\
(4.721)\end{array}$ & $* *$ & $\begin{array}{l}-2.897 \\
(6.143)\end{array}$ & & $\begin{array}{l}-2.897 \\
(6.143)\end{array}$ & \\
\hline \multicolumn{13}{|l|}{ ECD2 } \\
\hline All households & 478 & 71.967 & 74.477 & $\begin{array}{l}-2.510 \\
(3.842)\end{array}$ & 80.753 & 80.753 & $\begin{array}{c}0.000 \\
(3.842)\end{array}$ & & $\begin{array}{c}2.510 \\
(4.422)\end{array}$ & & $\begin{array}{c}2.510 \\
(4.422)\end{array}$ & \\
\hline Households with children under 6 years & 261 & 94.776 & 94.488 & $\begin{array}{c}0.288 \\
(2.882)\end{array}$ & 91.045 & 96.850 & $\begin{array}{l}-5.806 \\
(2.882)\end{array}$ & $* *$ & $\begin{array}{l}-6.094 \\
(3.904)\end{array}$ & & $\begin{array}{c}-6.094 \\
(3.904)\end{array}$ & \\
\hline
\end{tabular}


Table 13: Number of observations per group of analysis

\begin{tabular}{|c|c|c|c|c|c|c|c|c|c|c|c|c|c|c|c|c|}
\hline & \multirow[b]{2}{*}{ Total } & \multicolumn{2}{|c|}{ Education } & \multicolumn{3}{|c|}{ Village Size } & \multicolumn{3}{|c|}{ Altitude } & \multicolumn{2}{|c|}{ Gender } & \multicolumn{3}{|c|}{ Age } & \multicolumn{2}{|c|}{ Mother Tongue } \\
\hline & & Lower & Higher & Small & Medium & Large & Low & Medium & High & Female & Male & Younger & Middle & Older & $\begin{array}{l}\text { Quechua/ } \\
\text { Aymara }\end{array}$ & Spanish \\
\hline \multicolumn{17}{|l|}{ Motorized tracks } \\
\hline Households & 1521 & 965 & 556 & 510 & 480 & 344 & 407 & 402 & 443 & n.a. & n.a. & n.a. & n.a. & n.a. & n.a. & n.a. \\
\hline All individuals & 7574 & 4849 & 2725 & 2431 & 2471 & 1769 & 2082 & 1970 & 2193 & n.a. & n.a. & n.a. & n.a. & n.a. & 4936 & 2638 \\
\hline All members $>15$ years old & 3642 & n.a. & n.a. & 1360 & 1321 & 961 & 1127 & 1090 & 1193 & 2064 & 2077 & 1270 & 2091 & 780 & 2594 & 1547 \\
\hline Children $0-5$ years & 1396 & 881 & 515 & 424 & 465 & 334 & 389 & 351 & 399 & n.a. & n.a. & n.a. & n.a. & n.a. & 964 & 432 \\
\hline \multicolumn{17}{|l|}{ Boys } \\
\hline Males 6-11 years & 711 & 459 & 252 & 215 & 263 & 157 & 210 & 188 & 198 & n.a. & n.a. & n.a. & n.a. & n.a. & 483 & 228 \\
\hline Males $12-18$ years & 612 & 403 & 209 & 194 & 198 & 144 & 168 & 149 & 183 & n.a. & n.a. & n.a. & n.a. & n.a. & 401 & 211 \\
\hline \multicolumn{17}{|l|}{ Girls } \\
\hline Females 6-11 years & 734 & 466 & 268 & 239 & 233 & 180 & 195 & 197 & 218 & n.a. & n.a. & n.a. & n.a. & n.a. & 513 & 221 \\
\hline Females $12-18$ years & 521 & 331 & 190 & 165 & 168 & 124 & 144 & 130 & 153 & n.a. & n.a. & n.a. & n.a. & n.a. & 332 & 189 \\
\hline \multicolumn{17}{|l|}{ Non-Motorized tracks } \\
\hline Households & 474 & 303 & 171 & 185 & 126 & 111 & 89 & 124 & 168 & n.a. & n.a. & n.a. & n.a. & n.a. & n.a. & n.a. \\
\hline All individuals & 2348 & 1501 & 847 & 890 & 633 & 555 & 431 & 603 & 856 & n.a. & n.a. & n.a. & n.a. & n.a. & 1319 & 1029 \\
\hline All members $>15$ years old & 1181 & n.a. & n.a. & 488 & 350 & 343 & 230 & 362 & 478 & 662 & 660 & 421 & 661 & 240 & 732 & 590 \\
\hline Children $0-5$ years & 369 & 228 & 141 & 153 & 103 & 78 & 78 & 80 & 146 & n.a. & n.a. & n.a. & n.a. & n.a. & 223 & 146 \\
\hline \multicolumn{17}{|l|}{ Boys } \\
\hline Males 6-11 years & 232 & 156 & 76 & 83 & 62 & 48 & 37 & 58 & 79 & n.a. & n.a. & n.a. & n.a. & n.a. & 130 & 102 \\
\hline Males $12-18$ years & 212 & 143 & 69 & 83 & 51 & 53 & 42 & 52 & 80 & n.a. & n.a. & n.a. & n.a. & n.a. & 114 & 98 \\
\hline \multicolumn{17}{|l|}{ Girls } \\
\hline Females 6-11 years & 222 & 143 & 79 & 95 & 67 & 31 & 42 & 49 & 85 & n.a. & n.a. & n.a. & n.a. & n.a. & 129 & 93 \\
\hline Females $12-18$ years & 172 & 98 & 74 & 55 & 50 & 52 & 32 & 57 & 58 & n.a. & n.a. & n.a. & n.a. & n.a. & 89 & 83 \\
\hline
\end{tabular}

Notes: Heterogeneous categories are defined as follows. Education: Lower is for household head with primary or no education; Higher, with secondary or higher education. Village size: Small is for villages with less than 300 inhabitants; Medium, with more than 300 to 850 inhabitants; Large, with more than 850 inhabitants. Altitude: Low is for villages which are 2500 meters above sea level, Medium, between 2500 and 3400 meters above sea level, High, from more than 3400 to 5500 meters above sea level. Gender. if the individual is female or male. Age: Cohort 1 is for indivuduals younger than 25 years old, Cohort 2, from 26 to 50 years old; Cohort 3 , older than 50 . Mother tongue: if the mother tongue of the household head is quechua/aymara or spanish. 